\begin{tabular}{|l|c|c|c|r|}
\hline $\begin{array}{l}\text { Cuadernos de Investigación Geográfica } \\
\text { Geographical Research Letters }\end{array}$ & 2017 & N $^{\circ} 43(1)$ & pp. 141-169 & $\begin{array}{r}\text { ISSN 0211-6820 } \\
\text { eISSN 1697-9540 }\end{array}$ \\
\hline
\end{tabular}

\title{
ANALYSING THE EFFECT OF LAND USE AND VEGETATION COVER ON SOIL INFILTRATION IN THREE CONTRASTING ENVIRONMENTS IN NORTHEAST SPAIN
}

\author{
D. REGÜÉS ${ }^{1 *}$, D. BADÍA ${ }^{2}$, M.T. ECHEVERRÍA ${ }^{3}$, M. GISPERT ${ }^{4}$, \\ N. LANA-RENAULT ${ }^{5}$, J. LEÓN $^{3}$, E. NADAL-ROMERO ${ }^{3}$, \\ G. PARDINI ${ }^{4}$, P. SERRANO-MUELA ${ }^{1}$
}

\footnotetext{
${ }^{1}$ Instituto Pirenaico de Ecología (IPE-CSIC), Campus de Aula Dei, P.O. Box 13034, 50080 Zaragoza, Spain.

${ }^{2}$ Escuela Politécnica Superior de Huesca, Universidad de Zaragoza, Huesca, Spain. ${ }^{3}$ Departamento de Geografía y Ordenación del Territorio, Universidad de Zaragoza, 50009 Zaragoza, Spain. ${ }^{4}$ Departamento de Ingeniería Química, Agraria y Tecnología Agroalimentaria, Universitat de Girona, Girona, Spain. ${ }^{5}$ Departamento of Ciencias Humanas-Geografía Física, Universidad de La Rioja, 26004 Logroño, Spain.
}

ABSTRACT. This study presents a joint analysis of the information from 195 field infiltration experiments, using double ring devices. The experiments were carried out in 20 contrasting types of land use, distributed across three geographic contexts (coast of NE Catalonia, an area of gentle relief in the central Ebro Valley and mid-height mountains from the southern range of the Central Pyrenees). The objective of this research was to determine the most important factors explaining infiltration variability: land use, type of vegetation cover, soil and bedrock characteristics, soil moisture and altitude. Data analysis was performed by comparing variables using statistical methods: bivariate lineal correlation, ANOVA and Bonferroni multiple comparison tests. Results show that infiltration variability is the most important factor and is mainly linked to land use, followed by vegetation type. In contrast, soil moisture did not show any relation with infiltration. The interpretation of these results suggests that the characteristics of the study areas are more decisive than temporal variations of soil water content, although humidity can influence land use to a greater or lesser degree. The validity of the results obtained in this study is supported by the wide range of land use and land cover analysed, located in areas with different geographical and geological characteristics.

Análisis del efecto de los usos del suelo y de la cubierta vegetal en las tasas de infiltración en tres áreas contrastadas del Nordeste de España

RESUMEN. Este estudio presenta el análisis conjunto de la información obtenida a partir de 195 ensayos de infiltración en el campo, que fueron realizados mediante dispositivos de doble anillo. Los experimentos se realizaron en 20 situaciones contrastadas de usos del suelo, los cuales se encuentran distribuidos en tres 
contextos geográficos (costa NE de Cataluña, un área de relieves bajos del sector central del valle del Ebro y montaña media de la vertiente Sur del Pirineo central). El objetivo de esta investigación es determinar los factores más importantes que explican la variabilidad de la infiltración: uso del suelo, tipo de cubierta vegetal, características del suelo y del substrato rocoso, humedad del suelo y altitud. El análisis de los datos se realizó mediante la comparación de las variables a partir de distintos métodos estadísticos: test de correlación lineal bivariada, ANOVA y comparaciones múltiples de Bonferroni. Los resultados muestran que la variabilidad de la infiltración está principalmente asociada al tipo de uso del suelo, siendo el factor más determinante. El tipo de cubierta vegetal se mostró como el segundo factor en importancia, mientras la humedad del suelo no presentó correlación con la infiltración. La interpretación de estos resultados sugiere que las características de las áreas de estudio son más determinantes que las variaciones temporales del estado hídrico del suelo, aunque la humedad pueda tener un grado de influencia mayor o menor en cada uso del suelo. La validez de los resultados obtenidos en este estudio está avalada porque se ha analizado un amplio espectro de escenarios de uso del suelo/cubierta vegetal, incluso teniendo en cuenta que se han comparado zonas con distintas características geográficas y geológicas.

Key words: infiltration, double ring test, land use, vegetation cover, soil moisture, northeastern Spain.

Palabras clave: infiltración, ensayos con doble anillo, usos del suelo, cubierta vegetal, humedad del suelo, nordeste de España.

* Corresponding author: David Regüés, Instituto Pirenaico de Ecología (IPE-CSIC), Campus de Aula Dei, P.O. Box 13.034, 50080 Zaragoza, Spain. E-mail address: dregues@ ipe.csic.es

\section{Introduction}

The variation of saturated hydraulic conductivity $\left(\mathrm{K}_{\text {sat }}\right)$ and infiltration rates associated with vegetation cover/land use changes were examined in previous research (Zimmermann et al., 2006; Zimmermann and Elsenbeer, 2008) and linked to the influence of alterations in the physical properties of soil, which can affect both the spatial (Sisson and Wierenga, 1981; Hopmans et al., 1988; Mallants et al., 1996; Strock et al., 2001) and temporal (Moret and Arrúe, 2007; Bormann and Klaassen, 2008; Zhou et al., 2008; Li et al., 2009) variability of hydraulic properties. However, the temporal variability of hydraulic soil properties is less well documented than its spatial counterpart (Mishar et al., 2003; Hu et al., 2009). Many studies have described a decrease in infiltrability with depth in most land uses 
(Bonell et al., 1983; Malmer, 1996; Godsey et al., 2004; Zimmerman et al., 2006) except for pastures, where this variable is more stable or may increase (Malmer, 1996; Noguchi et al., 2003). However, the decrease in infiltrability was generally more pronounced in scenarios strongly affected by changes in land use and vegetation cover (Giertz and Diekkrueger, 2003; Martinez and Zinck, 2004; Ziegler et al., 2004; Moraes et al., 2006; Zimmermann et al., 2006) or affected by variations in tillage practices (Wang et al., 2016).

Many studies have demonstrated that vegetation cover significantly affects the hydrological response at catchment scale (Bosch and Hewlett, 1982; Trimble et al., 1987; Sahin and Hall, 1996; Stednick, 1996; Gallart and Llorens, 2003; Andréassian, 2004; Brown et al., 2005; García-Ruiz et al., 2008), with large reductions in the magnitude and frequency of floods being linked to an increase in forest cover (Beguería et al., 2003; López-Moreno et al., 2006; Lana-Renault et al., 2011), which adversely affects the water available for storage in reservoirs (García-Ruiz and Lana-Renault, 2011). Vegetation also has a protective effect against erosion by reducing rainfall splash and runoff drag force (Cerdà, 1999; Zhao et al., 2016).

Since the middle of the 20th century, a large area of agricultural land in Spain has been affected by the abandonment of crops (Romero-Díaz et al., 2007; Cerdà et al., 2012; Alonso-Sarriá et al., 2016), especially in mountain areas (Lasanta, 1988; Arnáez et al., 2011), resulting in natural vegetation colonisation and the growth of scrublands and forests (Molinillo et al., 1997; Poyatos et al., 2003; Vicente-Serrano et al., 2004). Another consequence is the reduction of subalpine grasslands (Lasanta and Vicente-Serrano, 2007), which has been related to the decline of grazing and the ascent of the upper tree line due to global warming (Sanjuán et al., 2013). The reduction of meadows and increase in scrubland in mountain areas is a widespread process in the Pyrenees (Camarero et al., 2015). Gartzia, et al. (2016) showed that, below $2100 \mathrm{~m}$ a.s.l., the presence of scrubland in areas previously occupied by grassland has increased significantly during the last few years and that there are significantly more trees in areas previously dominated by scrub.

In addition to the hydrological consequences associated with substantial expansion of forests and scrub, other environmental issues occur, such as the increased risk of fire (García-Ruiz and Lana-Renault, 2011; San Román et al., 2013). The effect of fire on soil properties has also been studied (Badía and Martí, 2003; Pardini et al., 2004b), particularly the hydric effects of an ash layer covering the soil surface, where responses vary according to the severity of fire (Pereira et al., 2013), as well as those deriving from fire on water, and sediment yield on different soil types (Badía et al., 2008). During the period immediately after fire, the ash deposit can increase infiltration capacity rates (Cerdà and Doerr, 2008; Zavala et al., 2009) in addition to causing a water repellent effect (Shakesby and Doerr, 2006; Bodí et al., 2012).

All these arguments justify the interest in improving knowledge on the relationships among land uses, the hydraulic properties of soil and overland flow generation (Germer et al., 2010; Price et al., 2010). Many studies on infiltration have focused on the application of models for comparison or validation using data obtained through 
laboratory or field infiltrometry tests, including comparisons between different land uses (Mbagwu, 1995; Mishar et al., 2003; Shukla et al., 2003; Ghorbani Dashtaki et al., 2009; Haghighi et al., 2010; Duan et al., 2011; Robertson and Sharp, 2015). Despite the large number of studies on the effect of land use changes on infiltration rates (Malmer and Grip, 1990; Ghuman et al., 1991; Alegre and Cassel, 1996; Lal, 1996; Navar and Synnott, 2000; Martínez and Zinck, 2004; Ziegler et al., 2004; Zimmermann et al., 2006), additional information from studies comparing contrasting areas is still needed. In this study, we analysed a large data set of infiltration rates measured under several land use and vegetation cover situations in three study areas in northern Spain, in order to determine their effect on infiltration variability.

\section{Material and methods}

\subsection{Study area}

The experimental areas were located in the north-eastern sector of the Iberian Peninsula (Fig. 1) which includes a wide variety of land uses and vegetation covers (Table 1):

(1) In the central-western Spanish Pyrenees (close to the city of Jaca), the sampled area contained low to medium-height mountains (700-1350 m a.s.l.) characterised by the presence of many abandoned fields in various stages of plant colonization (García-Ruiz and Lasanta, 1990), alternating with natural and artificial open and dense forest. The study area involves bare badlands, badlands covered with grass, south-facing pasture, north-facing meadows, south-facing slopes with natural forest (Quercus faginea) and north-facing slopes with natural forest (Pinus sylvestris and Fagus sylvatica).

(2) In the Ebro valley the sampled area is located in the Zuera structural platform (450-700 m a.s.1.), that contains a mixed forest (Castejón area) of Pinus halepensis, and scrubland (Remolinos area), including Genista Scorpius, Retama sphaerocarpa, Rosmarinus officinalis and Quercus coccifera. This area was burned in 2008 and 2009 (León et al., 2013). The experimental plots were selected based on a combination of three factors: vegetation cover, lithology of the bedrock and the occurrence/non-occurrence of fire. Thus, seven land uses were selected, including burned forest (south and north aspects), burned trees and scrubs (limestone and gypsum), burned scrub (gypsum), trees and scrubs (gypsum) and scrubs (gypsum).

(3) In the north-eastern coast of Spain (Cap de Creus, 90-260 m a.s.1.), which displays heavy human disturbance of the landscape, several types of land use, and vegetation cover associated with land abandonment due to reduced agricultural activity (Dunjó et al., 2003). The study was carried out on seven scenarios: north-facing pasture, scrubland (Erica and Cistus), pine and cork tree plantations, olive groves and vineyards. 


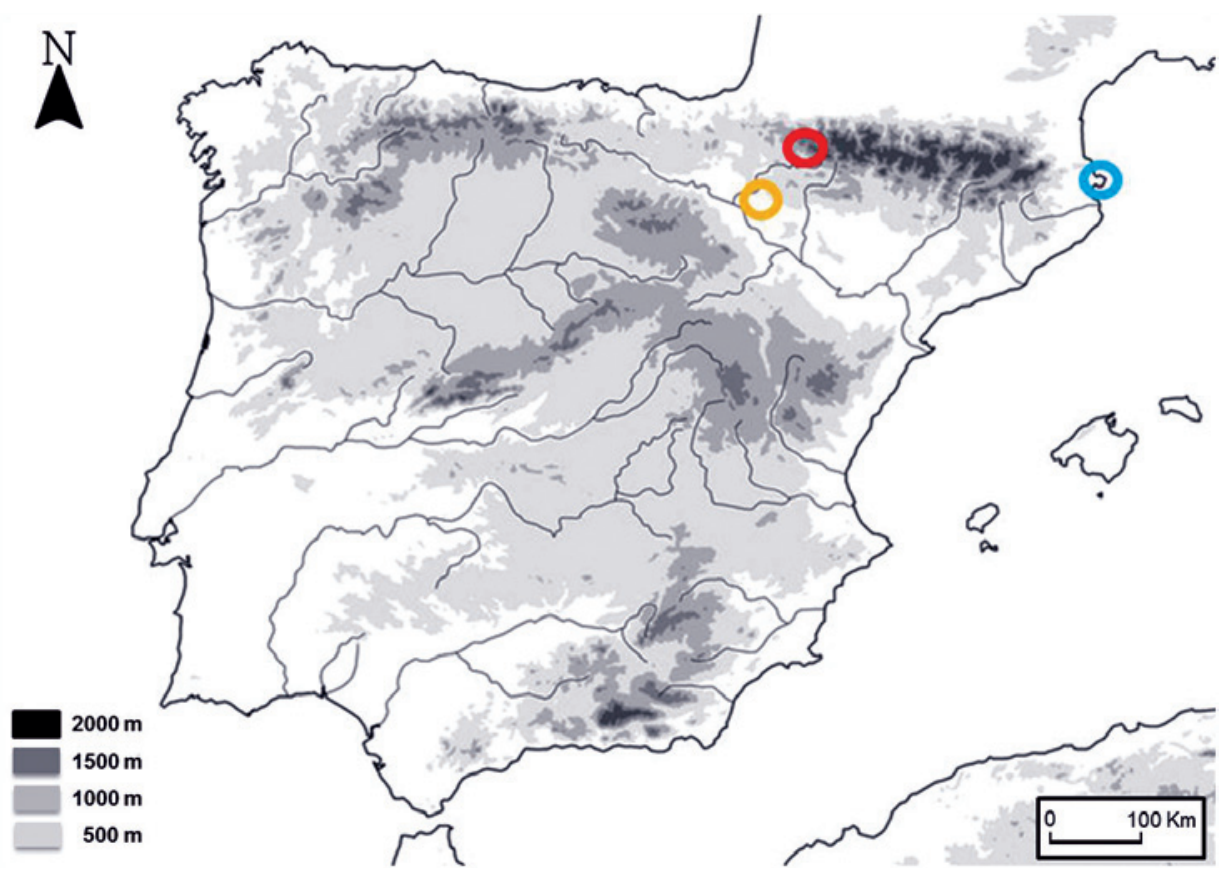

Figure 1. Situation of the study areas in the Iberian Peninsula: Pyrenees/Jaca area (red circle),

Ebro valley/Zuera (orange circle) and north-eastern coast/Cap de Creus (blue circle).

Table 1. Main features of the 20 land use/vegetation cover types in the study.

\begin{tabular}{cccc}
\hline Study site & Landscape & Land use (vegetation cover) & $\begin{array}{c}\text { Altitude } \\
(\mathbf{m})\end{array}$ \\
\hline Pyrenees (Jaca) & Middle mountain & Badlands (bare soil) & 780 \\
\hline Pyrenees (Jaca) & Middle Mountain & Badlands (grass+scrub) & 780 \\
\hline Pyrenees (Jaca) & Middle Mountain & Pasture south (grass) & 920 \\
\hline Pyrenees (Jaca) & Middle Mountain & Meadow north (grass+scrub) & 920 \\
\hline Pyrenees (Jaca) & Middle Mountain & Forest south (trees+scrub) & 1000 \\
\hline Pyrenees (Jaca) & Middle mountain & Forest north (trees+scrub) & 1000 \\
\hline Ebro valley (Zuera) & Low mountain & Burned forest south (trees+scrub) & 615 \\
\hline Ebro valley (Zuera) & Low mountain & Burned forest north (trees+scrub) & 475 \\
\hline Ebro valley (Zuera) & Middle mountain & Burned forest gypsum north (trees+scrub) & 700 \\
\hline Ebro valley (Zuera) & Low mountain & Burned forest limestone north (trees+scrub) & 415 \\
\hline Ebro valley (Zuera) & Low mountain & Burned scrub gypsum north (scrub) & 515 \\
\hline Ebro valley (Zuera) & Middle mountain & Forest gypsum north (trees+scrub) & 700 \\
\hline Ebro valley (Zuera) & Low mountain & Scrub gypsum north (scrub) & 515 \\
\hline NE coast (Cap de Creus) & Flat & Vineyard (scrub) & 90 \\
\hline NE coast (Cap de Creus) & Hill & Olive grove (trees) & 180 \\
\hline NE coast (Cap de Creus) & Hill & Cork tree plantation (trees) & 190 \\
\hline NE coast (Cap de Creus) & Hill & Pine tree plantation (trees) & 210 \\
\hline NE coast (Cap de Creus) & Hill & Pasture (grass) & 260 \\
\hline NE coast (Cap de Creus) & Hill & Scrub Cistus (scrub) & 240 \\
\hline NE coast (Cap de Creus) & Hill & Scrub Erica (scrub) & 230 \\
\hline
\end{tabular}


The dominant climatic conditions in the three areas are Mediterranean, although with some variations derived from the distance to the coast and altitude. The northeastern coastal area (Cap de Creus) shows the most marked characteristics of the Mediterranean climate, with strong prevailing winds from the north (Tramuntana) that reaches $90 \mathrm{~km}$ $\mathrm{h}^{-1}$. The mean annual temperature is about $16^{\circ} \mathrm{C}$ and the mean precipitation $450 \mathrm{~mm} \mathrm{yr}^{-1}$. In the Ebro Valley area (Zuera), the climate is Mediterranean with continental features and a very high water deficit (Herrero and Synder, 1997). The mean annual temperature is significantly lower $\left(12^{\circ} \mathrm{C}\right)$ and the mean annual precipitation is approximately 400 $\mathrm{mm} \mathrm{yr}^{-1}$. Climate characteristics in the sampled area of the central-western Pyrenees have been defined as sub-Mediterranean mountain, with distinct Mediterranean and, especially, Atlantic influences (Creus, 1983). Mean annual temperature is $10^{\circ} \mathrm{C}$ and mean precipitation of approximately $900 \mathrm{~mm} \mathrm{yr}^{-1}$.

Soils in the north-eastern coastal area (Cap de Creus) are shallow Lithic Xerorthent, and bedrock is composed of granodiorite and schists (Enram et al., 2012). Bedrock in the Ebro valley area (Zuera) is formed by Miocene limestones and gypsum, and soils are Rendzic Phaeozem, Leptic and Haplic Gypsisol (Badía et al., 2013; León et al., 2015a). The greatest soil diversity is found in the Pyrenees area (Jaca), with Kastanozem, Phaeozem, calcic Regosol, Leptosol or Cambisol, and bedrock is composed of Eocene Flysch turbidites in the Pyrenean mountain range and Eocene marls in the Inner Pyrenean Depression (García-Ruiz et al., 2008; Lana-Renault et al., 2011). Table 2 shows some descriptive characteristics of the soil types in each study site.

Table 2. Descriptive characteristics of the soils regarding its study site, vegetation cover and land use.

\begin{tabular}{|c|c|c|c|c|c|c|c|c|}
\hline $\begin{array}{l}\text { Study } \\
\text { site }\end{array}$ & $\begin{array}{l}\text { Vegetation } \\
\text { cover }\end{array}$ & Land use & $\begin{array}{c}\text { Soil } \\
\text { classification }\end{array}$ & $\begin{array}{c}\text { Sand } \\
\%\end{array}$ & $\begin{array}{c}\text { Silt } \\
\%\end{array}$ & $\begin{array}{c}\text { Clay } \\
\%\end{array}$ & $\begin{array}{l}\text { Avg. } \\
\text { OM \% }\end{array}$ & $\begin{array}{c}\text { Depth } \\
\text { (cm) }\end{array}$ \\
\hline \multirow{6}{*}{$\begin{array}{l}\text { Pyrenees } \\
\text { (Jaca) }\end{array}$} & Bare & Badland N & Regolith & 0 & 75 & 25 & 1.05 & 10 \\
\hline & \multirow{3}{*}{ Grass } & Badland & Regosol & 1.5 & 74 & 24.5 & 1.66 & 20 \\
\hline & & Pasture $\mathrm{S}$ & Leptosol & 3.5 & 75 & 21.5 & 1.75 & 50 \\
\hline & & Meadow N & Cambisol & 5 & 74 & 21 & 1.82 & 90 \\
\hline & \multirow{2}{*}{ Trees } & Forest $\mathrm{S}$ & Kastanozem & 12 & 66 & 22 & 2.83 & 100 \\
\hline & & Forest N & Phaeozem & 32 & 48 & 20 & 5.55 & 104 \\
\hline \multirow{7}{*}{$\begin{array}{c}\text { NE coast } \\
\text { (Cap } \\
\text { Creus) }\end{array}$} & Grass & Pasture N & \multirow{7}{*}{$\begin{array}{l}\text { Lithic Xeror- } \\
\text { thent }\end{array}$} & 62.5 & 20 & 17.5 & 6.79 & 25 \\
\hline & \multirow{3}{*}{ Scrub } & Vineyard N & & 85 & 11 & 4 & 0.62 & 40 \\
\hline & & Erica N & & 64 & 23 & 13 & 6.12 & 35 \\
\hline & & Cistus N & & 55 & 25 & 20 & 4.72 & 33 \\
\hline & \multirow{3}{*}{ Trees } & Pine N & & 67.5 & 21 & 12.5 & 3.10 & 40 \\
\hline & & Cork $\mathrm{N}$ & & 61.5 & 27.5 & 11 & 5.08 & 37 \\
\hline & & Olive $\mathrm{N}$ & & 65.5 & 20 & 14.5 & 2.41 & 38 \\
\hline \multirow{3}{*}{$\begin{array}{c}\text { Ebro } \\
\text { valley } \\
\text { (Zuera) }\end{array}$} & \multirow{2}{*}{ Scrub } & Unburned N & Leptic Gypsisol & 28 & --- & --- & 1.76 & 60 \\
\hline & & Burned N & \multirow{2}{*}{ Haplic Gypsisol } & 22 & --- & --- & 2.00 & 60 \\
\hline & Trees & Burned N & & 22 & --- & --- & 2.00 & 75 \\
\hline
\end{tabular}




\begin{tabular}{|c|c|c|c|c|c|c|c|c|}
\hline \multirow{4}{*}{$\begin{array}{c}\text { Ebro } \\
\text { valley } \\
\text { (Zuera) }\end{array}$} & \multirow{4}{*}{ Trees } & Unburned $\mathrm{N}$ & Leptic Gypsisol & 28 & --- & --- & 1.76 & 75 \\
\hline & & Burned lim. N & \multirow{3}{*}{$\begin{array}{l}\text { Rendzic Phaeo- } \\
\text { zem }\end{array}$} & 22 & 44 & 34 & 7.00 & 90 \\
\hline & & Burned N & & 31 & 52 & 17 & 1.77 & 90 \\
\hline & & Burned S & & 31 & 52 & 17 & 1.77 & 90 \\
\hline
\end{tabular}

\subsection{Methodology}

Data acquisition was performed by double ring infiltrometer tests in the Pyrenees and Cap de Creus study sites, using devices of similar design, with an inner cylinder diameter of $29.5 \mathrm{~cm}$ (external cylinder diameter $49.5 \mathrm{~cm}$ ). For the tests performed in the Ebro Valley, a simple ring infiltrometer, with a smaller inner cylinder $(15 \mathrm{~cm})$ diameter was used. In order to analyze differences between these two types of infiltrometers, several tests were performed simultaneously with both devices in the Ebro valley experimental area to obtain a correction coefficient. The simple ring infiltrometer returned rather higher mean infiltration rates (2.74 times); therefore, this coefficient was applied to all results obtained from the Ebro Valley tests.

Different scenarios of land use and vegetation cover were selected for the experimental plots, taking the most representative environments of each study site (Pyrenees, Ebro Valley and Cap de Creus).

Experiments were carried out under different soil moisture conditions, including situations of high, medium and low humidity. Former infiltration studies enabled an average value of saturated hydraulic conductivity $\left(\mathrm{K}_{\text {sat }}\right)$ to be calculated, corresponding to the final value of infiltration rates obtained in each test (infiltration is the term that will be used throughout the paper). Data from all tests were analysed using simple descriptive statistics (median, average, standard deviation, maximum, minimum and percentiles), bivariate linear correlations, ANOVA and Bonferroni tests for multiple comparisons (IBM SPSS Statistics 22, 2013), which were applied to the total data set and to the average values obtained for each type of land use and vegetation cover.

The variables included in the study were: study area, land use, type of vegetation cover, altitude (m a.s.1.), median and average infiltration $\left(\mathrm{mm} \mathrm{h}^{-1}\right)$ and soil moisture (percentage value) measured through sampling at 0-5 $\mathrm{cm}$ soil depth.

\section{Results}

A description of the infiltration tests is shown in Table 3, including land use (20 types), vegetation cover (6 types), number of tests performed for each land use, as well as average, median and standard deviation of moisture and infiltration rates. Land uses were classified from lower to higher infiltration rates. A total number of 195 tests were performed: 20 were carried out in the Pyrenees (Jaca), 64 in the Ebro valley (Zuera) and 111 in the northeastern coast (Cap de Creus) areas. The distribution of the tests was: 3 in bare soils, 25 in grass, 47 in scrub, 62 in forests, 8 in burned scrub and 50 in burned forest. 


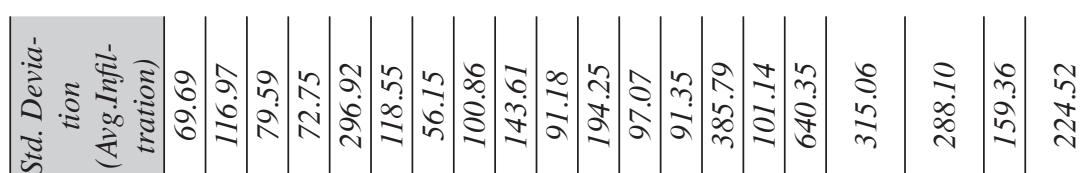

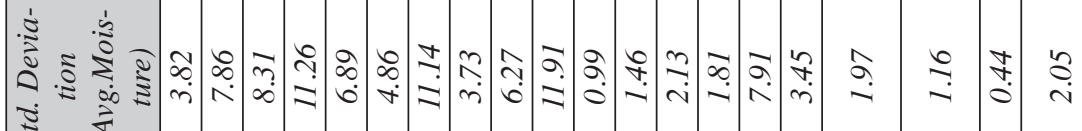

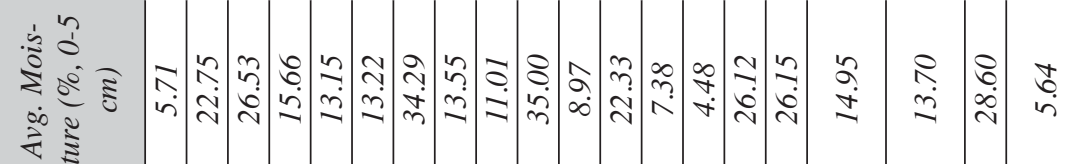
$\because$ a

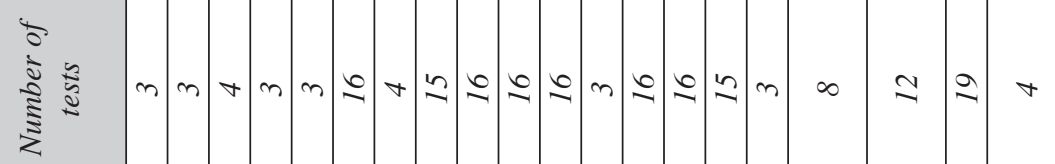

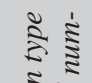

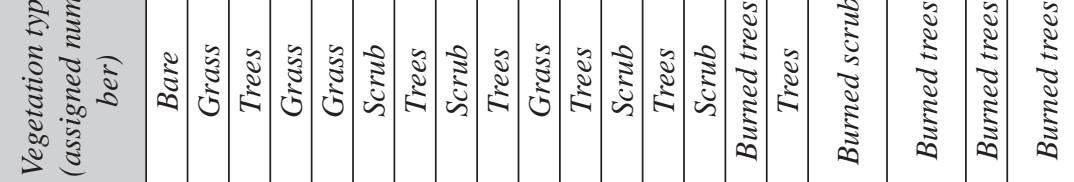

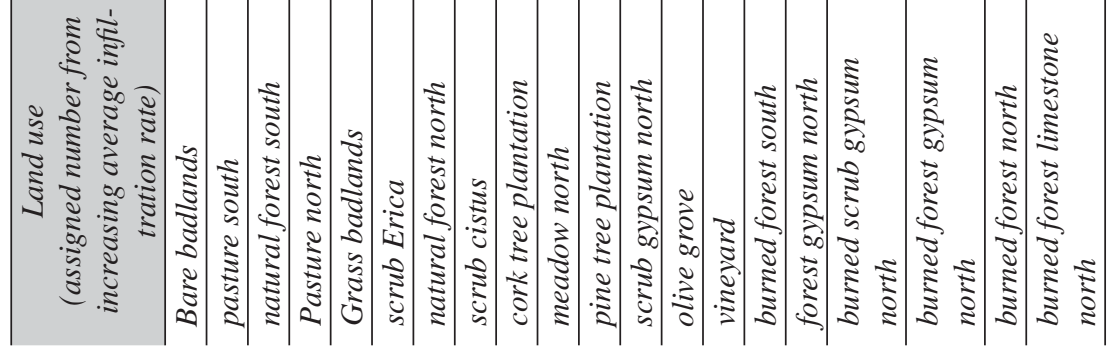




\subsection{Infiltration variability in relation to the study sites}

Figure 2 shows average, median and standard deviation values from the 195 infiltration tests. Land uses were classified by ascending average infiltration rates to analyze whether the distribution showed any interesting relationship with land uses, study sites and type of vegetation cover. Median and, especially, standard deviations were not in proportion to the average infiltration rate, indicating that its variance is not proportional to its value. However, the most important observation from the classification of land use was that distribution seemed to be fairly well related to the study site. Thus, the lowest values corresponded to the Pyrenees (Jaca), the intermediates were on the northeastern coast (Cap de Creus) and the highest were in the Ebro valley (Zuera). This result must be statistically explored to assess whether this factor should be taken into account in data analysis.

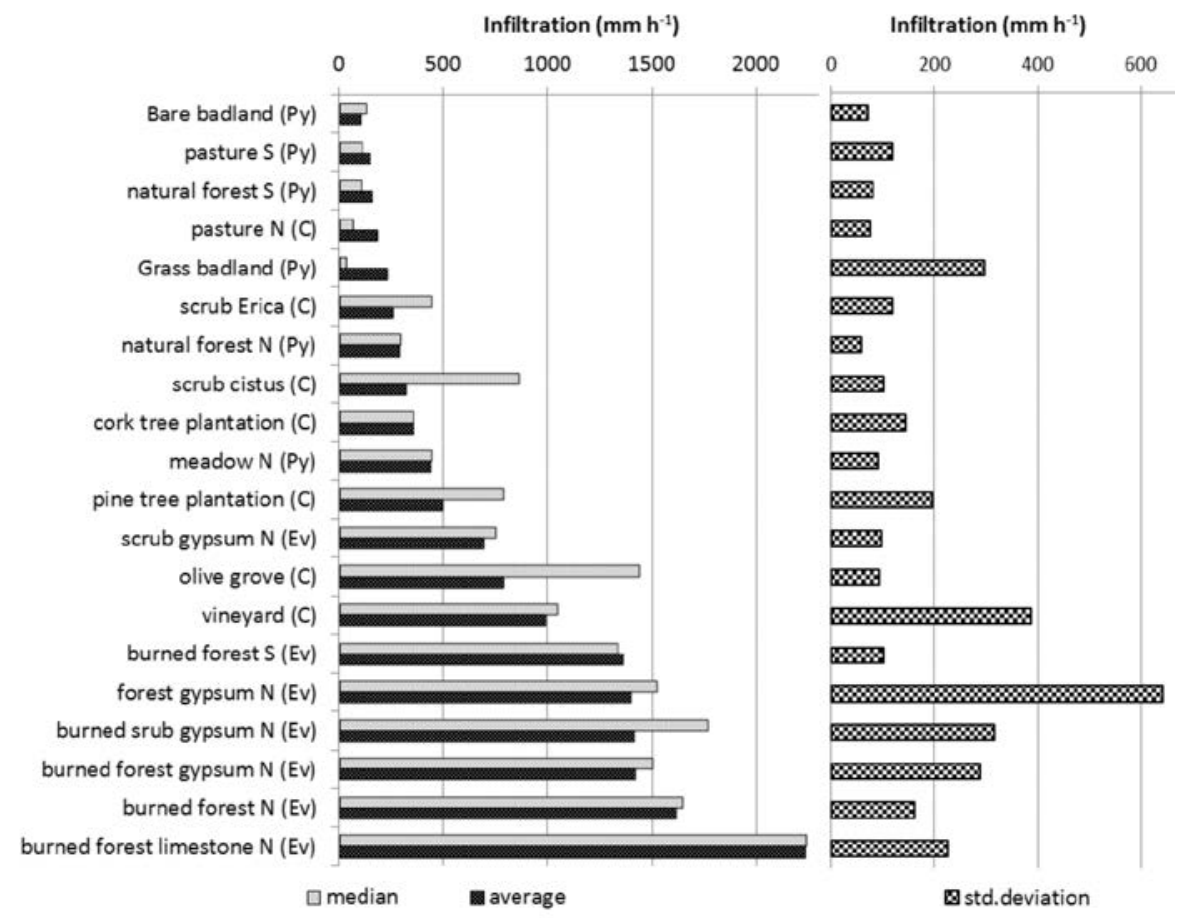

Figure 2. Average, median and standard deviation values of infiltration rates. Land uses are ranked from low to high average infiltration values. Py: Pyrenees/Jaca; C: north-eastern coast/Cap de Creus; Ev: Ebro valley/Zuera.

Linear correlations between quantitative variables (average infiltration, altitude and moisture), showed a good correlation of altitude with moisture and average infiltration, although it was somewhat lower in this case, and no correlation was found between average infiltration rates and moisture (Table 4). This result suggests that the average infiltration rates may be more strongly linked to the characteristics of 
the study sites than to soil water status. It seems logical to assume that infiltration rates were conditioned by the lithology of the substrate and the type of soil, since they showed significant differences in texture, average organic matter and soil depth (Table 2), although only soil depth showed a significant correlation with average infiltration rates (R: $0.568 ; \sigma: 0.009 ; \mathrm{N}: 20)$. Therefore, when analyzing the variance of infiltration rates with respect to type of land use and vegetation cover, the depth of the soil is implicitly taken into account.

Table 4. Results of lineal correlation for each of the 195 infiltration tests, the analysis includes 3 variables (altitude, infiltration rates and soil moisture).

Significant correlation at 0.001 level are in bold.

\begin{tabular}{lccc} 
& statistics & Altitude & Infiltration rate \\
\hline \multirow{3}{*}{ Infiltration rates } & Pearson coef. & $\mathbf{0 . 1 9 1}$ & \\
& Sig.bilat. & 0.008 & \\
& $N$ & 195 & \\
Moisture & Pearson coef. & $\mathbf{0 . 4 8 8}$ & 0.074 \\
& Sig.bilat. & 0.000 & 0.303 \\
& $N$ & 195 & 195 \\
\hline
\end{tabular}

The effect of the study site on infiltration rates and soil moisture was further analysed by statistical descriptors and by applying statistical comparative methods. Figure 3 shows that infiltration rates differed between study sites, but soil moisture presented a similar range of values. Results from the ANOVA and Bonferroni tests confirmed that infiltration rates were statistically different in all study sites (Table 5). Results of a moisture comparison from the ANOVA test showed differences between the sites, but the Bonferroni test confirmed that only the northeastern coast (Cap de Creus) differed from the Pyrenees (Jaca) and Ebro valley (Zuera), which showed similar moisture values. Land use and types of vegetation cover were more heterogeneous in the Pyrenees (Jaca) and northeastern coast (Cap de Creus) than in the Ebro valley (Zuera), where experimental conditions always took place in a forest or scrub environment. In this case, the only differential factors in defining land use were the effects of fire, the bedrock (limestone or gypsum) and its respective type of soil. Thus, these results confirm that the highest infiltration rates and least dispersion of soil moisture values occur in the environment affected by fire, in contrast with the lower infiltration and more dispersed soil moisture values observed in the Pyrenees area (Jaca), while in the northeastern coast (Cap de Creus) the values were intermediate in comparison with the other two sites (Figure 3). It should also be noted that the difference in infiltration rates observed among the three study sites could be partly due to variations in the experimental procedures, differences between the devices used, or even because tests were performed by different operators in each area. 

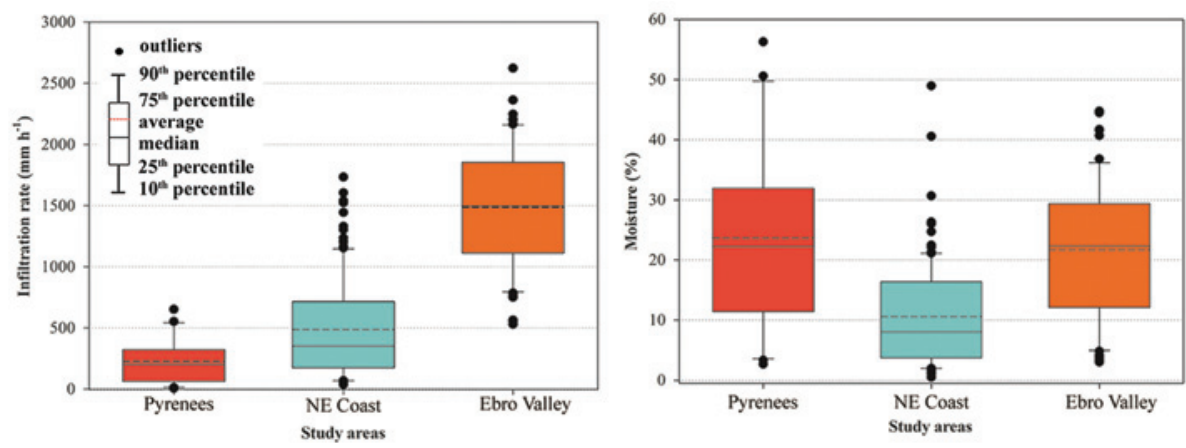

Figure 3. Results of 195 infiltration test for the respective study sites. (A) Infiltration rates $\left(\mathrm{mm} \mathrm{h}^{-1}\right)$. (B) Moisture (\%).

Table 5. Statistical comparison (ANOVA and Bonferroni test) of the infiltration rates and moisture for the 3 study sites. Significant coefficients are in bold.

\begin{tabular}{|c|c|c|c|}
\hline$A N O V A$ & $d f$ & $F$ & Sig. \\
\hline \multirow{3}{*}{ Infiltration $\left(m m \cdot h^{-1}\right)$} & 2 & & \\
\hline & 192 & 128.47 & 0.000 \\
\hline & 194 & & \\
\hline \multirow{3}{*}{ Moisture (\%) } & 2 & & \\
\hline & 192 & 29.30 & 0.000 \\
\hline & 194 & & \\
\hline Bonferroni & Study site (I) & Study site $(\mathrm{J})$ & Sig. \\
\hline \multirow{6}{*}{ Infiltration $\left(m m \cdot h^{-1}\right)$} & \multirow{2}{*}{ Pyrenees } & $N E$ coast & 0.042 \\
\hline & & Ebro Valley & 0.000 \\
\hline & \multirow{2}{*}{$N E$ coast } & Pyrenees & 0.042 \\
\hline & & Ebro Valley & 0.000 \\
\hline & \multirow{2}{*}{ Ebro valley } & Pyrenees & 0.000 \\
\hline & & $N E$ coast & 0.000 \\
\hline \multirow{6}{*}{ Moisture (\%) } & \multirow{2}{*}{ Pyrenees } & $N E$ coast & 0.000 \\
\hline & & Ebro Valley & 1.000 \\
\hline & \multirow{2}{*}{$N E$ coast } & Pyrenees & 0.000 \\
\hline & & Ebro Valley & 0.000 \\
\hline & \multirow{2}{*}{ Ebro valley } & Pyrenees & 1.000 \\
\hline & & $N E$ coast & 0.000 \\
\hline
\end{tabular}

\subsection{Infiltration and soil moisture variability in different land uses}

Figure 4 shows the statistical descriptors of the average infiltration rates obtained in each land use. The first thing to be noticed was that ranges vary widely and their variability has no relation to the average value of infiltration. In any case, such seemingly obvious differences among land uses must be confirmed by comparative statistical analysis before they can be adequately described. 
Regués et al.

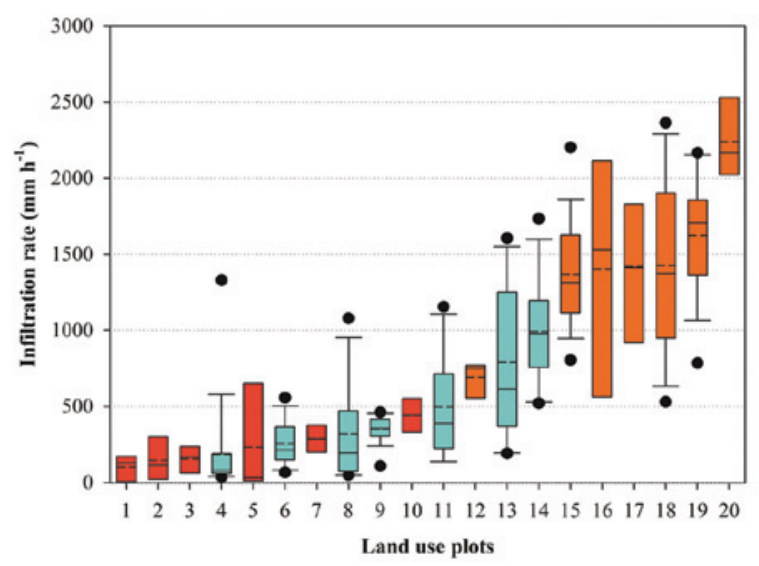

Figure 4. Statistic descriptors of infiltration rates for each land use, following the same classification as figure 2. Pyrenees/Jaca (Py), north-eastern coast/Cap de Creus $(C)$ and Ebro valley/Zuera (Ev): 1-badlands (Py); 2-pasture $S(P y)$; 3-forest $S(P y)$; 4-pasture $N(C)$; 5-grass Badlands (Py); 6-scrub Erica (C); 7-forest N (Py); 8-scrub Cistus (C); 9-cork tree plantation (C); 10-meadow $N(P y)$; 11-pine tree plantation $(C)$; 12-scrub gypsum $N(E v) ; 13$-olive grove

(C); 14-vineyard $(C)$; 15-burned forest $S(E v) ; 16$-forest gypsum $N(E v) ; 17$-burned scrub gypsum $N(E v) ; 18$-burned forest gypsum $N(E v) ; 19$-burned forest $N(E v) ; 20$-burned forest limestone $N(E v)$. The different colors are indicative of the experimental site to which each land use corresponds: Pyrenees (red), north-eastern coast (blue), Ebro valley (orange).

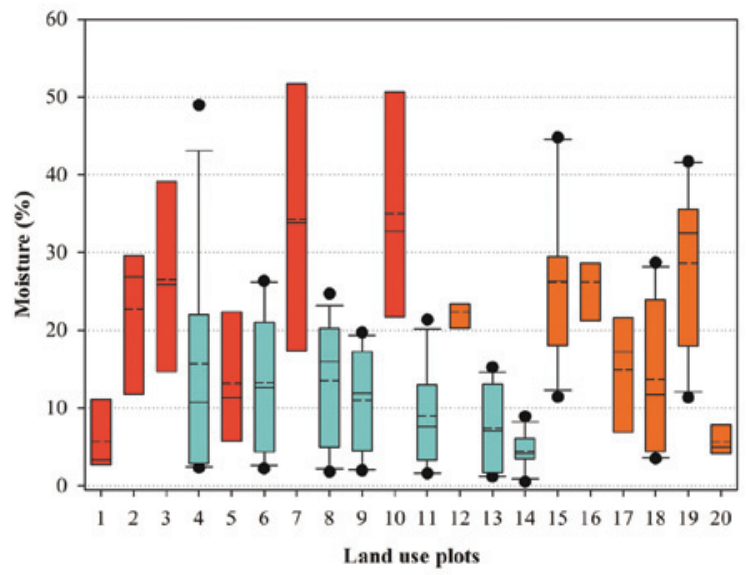

Figure 5. Statistical descriptors of moisture for each land use, following the same classification as figure 2. Pyrenees/Jaca (Py), north-eastern coast/Cap de Creus (C) and Ebro valley/Zuera (Ev): 1-badlands (Py); 2-pasture S (Py); 3-forest $S$ (Py); 4-pasture N (C); 5-grass Badlands

$(P y)$; 6-scrub Erica $(C)$; 7-forest $N(P y) ; 8$-scrub Cistus $(C)$; 9-cork tree plantation $(C)$; 10-meadow $N(P y)$; 11-pine tree plantation $(C)$; 12-scrub gypsum $N(E v)$; 13-olive grove $(C)$; 14-vineyard $(C)$; 15-burned forest limestone $S(E v)$; 16-forest gypsum $N(E v)$; 17-burned scrub gypsum $N(E v) ; 18$-burned forest gypsum $N(E v)$; 19-burned forest limestone $N(E v) ; 20$-burned forest limestone $N(E v)$. The different colors are indicative of the experimental site to which each land use corresponds: Pyrenees (red), north-eastern coast (blue), Ebro valley (orange). 
Figure 5 shows the statistical descriptors for the moisture values in each experimental plot. It is evident that there is no relationship between the average rates of infiltration and initial moisture in the experimental plots. This observation is consistent with the absence of linear correlation presented in Table 4.

The variability of infiltration rates between the land uses was analysed by a Bonferroni test (Table 6). The results indicate that land uses in the Ebro Valley (Zuera) show greater difference from the other two study sites, whereas most of the land uses in the Pyrenees (Jaca) and north-eastern coast (Cap de Creus) show statistical similarities. The land use that returns the greatest differences from the others is burned forest limestone, which is only similar to two of the other uses in the same study site. On the contrary, scrub gypsum in the Ebro Valley (Zuera) has similarities with all land uses in the experimental areas of the Pyrenees (Jaca) and north-eastern coast (Cap de Creus), with the only differences showing in two land uses (burned forest limestone and burned forest north) within its own study site. With respect to the land uses of the Pyrenees (Jaca) and north-eastern coast (Cap de Creus), the most outstanding result is observed in vineyards (which display the greatest differences from the others in these study sites, but greater similarities with those of the Ebro Valley). Olive groves and north-facing pasture are the other land uses in the north-eastern coast (Cap de Creus) and Pyrenees (Jaca) that have certain similarity with some uses in the Ebro Valley (Zuera), in addition to the scrub gypsum mentioned above. It is important to emphasize the position listed for grass badland (Pyrenees), which surprisingly is above that of the two pastures (Pyrenees and northeastern coast) and the southern forest (Pyrenees). The explanation is that, in one of the tests carried out in the grass badland, a very high infiltration rate was obtained, the highest of all the tests carried out in the Pyrenees (Jaca) experimental area. The statistical descriptors for Figure 4 give an excellent view of the effect of this possibly anomalous result. Listed at position 5 of land uses, it is easy to appreciate that values are very highly dispersed and the difference between the median and average value is too large, which confirms the occurrence of some irregularity between this result and those obtained in the other tests.

For a more in-depth study of the differences and similarities between land uses within each study site, ANOVA and Bonferroni tests were performed on each one. Table 7 presents the results of the statistical comparisons between land uses in the same experimental site, but in this case the analysis for the Pyrenees (Jaca) study site was done twice, the first included the previously mentioned anomalous result from the grass badland plot, which was excluded in the second. The analyses confirmed that, in the Pyrenees experimental site, the result of the anomalous test conditioned the statistical comparison, so that if included, the ANOVA test indicated that there was no statistically significant difference in infiltration rates for different land uses. However, if this result was excluded, the ANOVA test identified at least one use that showed significant differences, while the Bonferroni test identified the difference as being associated with the north-facing meadow, which only shows similarity with the northern forest. 


\begin{tabular}{|c|c|c|c|c|c|c|c|c|c|c|c|c|c|c|c|c|c|c|c|}
\hline 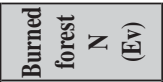 & & & & & & & & & & & & & & & & & & & $\begin{array}{l}\text { f: } \\
\text { a. } \\
0\end{array}$ \\
\hline 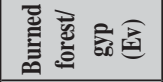 & & & & & & & & & & & & & & & & & & $\stackrel{8}{-}$ & : \\
\hline 总言佥会 & & & & & & & & & & & & & & & & & $\stackrel{8}{-}$ & 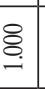 & 商 \\
\hline 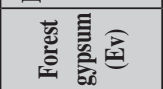 & & & & & & & & & & & & & & & & $\stackrel{8}{-}$ & $\underset{-}{.}$ & : & ঙ্ণী \\
\hline 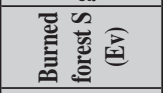 & & & & & & & & & & & & & & & $\underset{8}{8}$ & 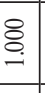 & 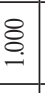 & 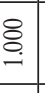 & 㟥 \\
\hline 蛋 & & & & & & & & & & & & & & : & $\stackrel{8}{-}$ & $\stackrel{8}{-}$ & 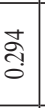 & : & हू. \\
\hline 言 啇仓 & & & & & & & & & & & & & $\underset{-}{8}$ & క్రి: & $\stackrel{8}{-}$ & $\bar{\Xi}$ & 高 & ह్ & ל్. \\
\hline 言憘畐 & & & & & & & & & & & & $\stackrel{8}{-}$ & $\underset{-}{8}$ & 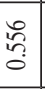 & $\stackrel{8}{-}$ & 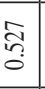 & बे & 言 & ) \\
\hline 导 & & & & & & & & & & & 8 & 8 & $\bar{\Xi}$ & ל: & $\stackrel{m}{3}$ & हू. & : & : & हू. \\
\hline 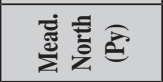 & & & & & & & & & & $\underset{-}{8}$ & $\underset{-}{-}$ & $\underset{-}{-}$ & $\underset{:}{8}$ & ל্ট் & క్ & 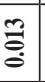 & 产 & 产 & 产 \\
\hline 音总 & & & & & & & & & 8 & 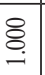 & $\underset{.}{\triangle}$ & $\stackrel{\infty}{=}$ & हू & ל్ర & $\bar{\Xi}$ & ל్రి: & ל్. & ל్. & ל్. \\
\hline 言善 & & & & & & & & $\stackrel{8}{-}$ & $\underset{-1}{8}$ & $\underset{8}{8}$ & $\underset{-}{8}$ & 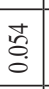 & ह్ర్: & : & $\overline{\mathrm{z}}$ & : & 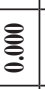 & 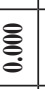 & : \\
\hline 总 & & & & & & & 8 & $\underset{8}{8}$ & 8 & 8 & 8 & 8 & $\overline{\sigma_{0}}$ & ל. & $\bar{\Xi}$ & לू. & 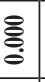 & ל: & ל్. \\
\hline 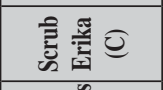 & & & & & & $\stackrel{8}{8}$ & $\stackrel{8}{8}$ & $\underset{-}{8}$ & 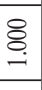 & $\underset{8}{8}$ & : & 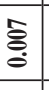 & हి & ל్. & 产 & ל్. & ל్. & ל: & ל్. \\
\hline 记 & & & & & 8 & $\stackrel{8}{-}$ & $\stackrel{8}{-}$ & $\stackrel{8}{-}$ & 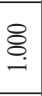 & $\stackrel{8}{-}$ & $\stackrel{8}{.}$ & $\stackrel{-}{-}$ & $\stackrel{8}{0}$ & हू. & 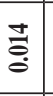 & हू. & 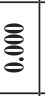 & 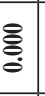 & हू. \\
\hline 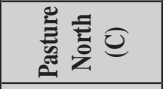 & & & & \&: & 8 & $\stackrel{8}{8}$ & $\stackrel{8}{8}$ & $\stackrel{8}{8}$ & 8 & \&: & 8 & छ⿳亠二口犬. & 言 & ל⿳亠口冋口. & ל⿳亠二口犬. & ל్. & ל: & ל⿳亠口冋口. & ל్. \\
\hline 产言司 & & & 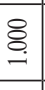 & 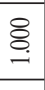 & $\underset{-8}{.}$ & $\stackrel{8}{8}$ & $\stackrel{8}{8}$ & $\underset{-}{8}$ & 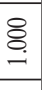 & $\underset{8}{8}$ & 8 & 商 & $\overline{\mathrm{z}}$ & ל⿳亠口冋口. & $\bar{\vdots}$ & ל్. & ל్. & ל్. & ל⿳亠口冋口. \\
\hline 言言 & & 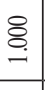 & 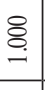 & $\stackrel{8}{8}$ & 8 & $\stackrel{8}{8}$ & $\stackrel{8}{8}$ & $\underset{-}{\stackrel{8}{-}}$ & $\underset{8}{\stackrel{8}{-}}$ & $\underset{8}{-}$ & $\underset{8}{-}$ & 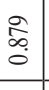 & $\begin{array}{l}\infty \\
\stackrel{0}{*} \\
\stackrel{\circ}{\circ}\end{array}$ & : & 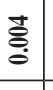 & ל్. & : & : & : \\
\hline 总高 & 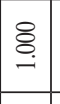 & 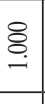 & $\underset{-}{-}$ & $\stackrel{8}{-}$ & 8 & $\stackrel{8}{-}$ & $\stackrel{8}{-}$ & $\underset{8}{-}$ & 8 & $\underset{-}{-}$ & _ి & 焘 & $\stackrel{\infty}{\vdots}$ & ל్ర్: & 亏ે̊. & ל్ర్ & हू. & : & ל్ర్: \\
\hline 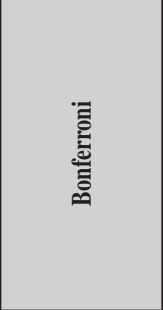 & 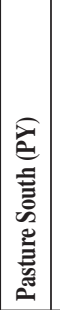 & 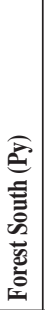 & 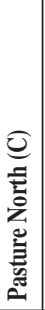 & 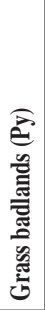 & 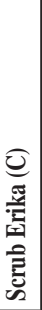 & 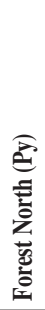 & 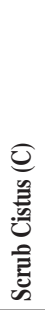 & 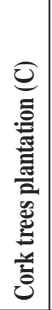 & 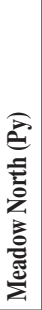 & 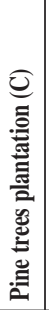 & 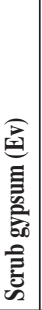 & 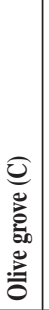 & 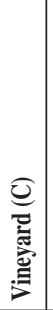 & 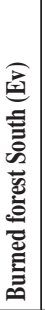 & 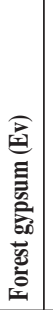 & 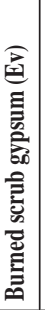 & 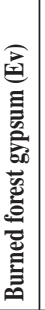 & 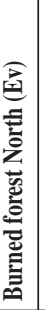 & 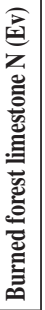 \\
\hline
\end{tabular}


Table 7. Comparison (ANOVA and Bonferroni tests) of infiltration rates for land use in the respective study sites: Pyrenees/Jaca (6 land uses, 20 tests); north-eastern coast/Cap de Creus (7 land uses, 111 tests); Ebro valley/Zuera (7 land uses, 64 tests). Only the significant differences are provided. Results of Pyrenees/Jaca marked with an asterisk were obtained without the exceptional value recorded in a grass badland experimental test.

\begin{tabular}{|c|c|c|c|}
\hline$A N O V A$ & $d f$ & $F$ & Sig. \\
\hline \multirow{6}{*}{ PYRENEES (JACA) } & 5 & 1.687 & 0.202 \\
\hline & 14 & & \\
\hline & 19 & & \\
\hline & $5 *$ & $6.136^{*}$ & $0.004^{*}$ \\
\hline & $13 *$ & & \\
\hline & $18^{*}$ & & \\
\hline Bonferroni & Study site (I) & Study site $(J)$ & Sig. \\
\hline \multirow{4}{*}{ PYRENEES (JACA) } & Badlands* & Meadow North* & $0.019 *$ \\
\hline & Pasture South* & Meadow North* & $0.050 *$ \\
\hline & Forest South* & Meadow North* & $0.040 *$ \\
\hline & Grass badlands* & Meadow North* & $0.008^{*}$ \\
\hline ANOVA & $d f$ & $F$ & Sig. \\
\hline \multirow{3}{*}{$N E$ coast (CAP DE CREUS) } & 6 & 14.163 & 0.000 \\
\hline & 104 & & \\
\hline & 110 & & \\
\hline Bonferroni & Study site (I) & Study site $(\mathrm{J})$ & Sig. \\
\hline \multirow{9}{*}{$N E$ coast (CAP DE CREUS) } & Pasture & Olive grove & 0.000 \\
\hline & & vineyard & 0.000 \\
\hline & Scrub Erica & Olive grove & 0.000 \\
\hline & & vineyard & 0.000 \\
\hline & Scrub Cistus & Olive grove & 0.002 \\
\hline & & vineyard & 0.000 \\
\hline & Cork trees & Olive grove & 0.004 \\
\hline & & vineyard & 0.000 \\
\hline & Pine trees & vineyard & 0.001 \\
\hline$A N O V A$ & $d f$ & $F$ & Sig. \\
\hline \multirow{3}{*}{ EBRO VALLEY (ZUERA) } & 6 & 4.151 & 0.002 \\
\hline & 57 & & \\
\hline & 63 & & \\
\hline Bonferroni & Study site $(\mathrm{I})$ & Study site $(\mathrm{J})$ & Sig. \\
\hline \multirow{4}{*}{ EBRO VALLEY (ZUERA) } & Scrub gypsum & Burned forest North & 0.026 \\
\hline & & Burned forest limestone & 0.001 \\
\hline & Burned forest South & Burned forest limestone & 0.018 \\
\hline & Burned forest gypsum & Burned forest limestone & 0.047 \\
\hline
\end{tabular}

The comparative analysis between the land uses in the experimental site of the northeastern coast (Cap de Creus) reveals that the greatest number of differences between uses occurs mainly with vineyards (which are only similar to olive groves), and olive groves (which are only similar to vineyards and pine trees). Lastly, the Ebro 
Valley (Zuera) experimental site shows the greatest homogeneity of results, especially considering the result from the Pyrenees (Jaca), where the anomalous test was ruled out. The land uses with the largest differences from the others are scrub gypsum (burned forest north and burned forest limestone) and burned forest limestone (scrub gypsum). In general, these results are consistent with those shown in Table 6, but also suggest that the comparison between the results may show some variations if an unreliable outcome is included or excluded. In any case, it is evident that the land uses show some remarkable differences, although probably the ones between experimental sites are more important than those within the experimental sites (see Fig. 3A and 4).

\subsection{Analysis of results from 6 vegetation types}

Data analysis was performed using six groups, each with similar vegetation (Table 8). The main difference from the other analyses was that, in this case, they are mixed infiltration rates obtained from different situations in experimental areas and land use.

Table 8. Summary of vegetation group features. L: low, M: medium; S: South, $N$ : North. Between brackets the number of soil uses included in the group from its respective experimental site.

\begin{tabular}{|c|c|c|c|c|c|c|}
\hline & Bare soil & Grass & Scrub & Forest & Burned scrub & Burned forest \\
\hline$S$ & \multirow[t]{4}{*}{ Pyrenees } & Pyrenees (3) & Ebro valley (1) & Pyrenees (2) & \multirow[t]{4}{*}{ Ebro valley (1) } & \multirow[t]{4}{*}{ Ebro valley (4) } \\
\hline$I$ & & $N E$ coast $(1)$ & $N E$ coast $(3)$ & Ebro valley (1) & & \\
\hline$T$ & & & & $N E$ coast $(3)$ & & \\
\hline$E$ & & & & & & \\
\hline$S$ & \multirow[t]{4}{*}{ Regolith } & Calcic Regosol & Leptic Gypsisol & Kastanozem & \multirow[t]{4}{*}{ Haplic Gypsisol } & \multirow{4}{*}{$\begin{array}{c}\text { Rendzic Phaeozem } \\
\text { Haplic Gypsisol }\end{array}$} \\
\hline $\boldsymbol{O}$ & & Leptosol & Lithic Xerorthent & Phaeozem & & \\
\hline$I$ & & Cambisol & & Rendzic Phaeozem & & \\
\hline$L$ & & Lithic Xerorthent & & Lithic Xerorthent & & \\
\hline$L$ & \multirow[t]{7}{*}{ Badlands } & Grass badlands & L. mountain $(N)$ & $M$. mountain $(S)$ & \multirow[t]{7}{*}{ L. mountain $(S)$} & L. mountain limestone $(S)$ \\
\hline$A$ & & M. mountain $(S)$ & Vineyard coast & $M$. mountain $(N)$ & & L. mountain limestone $(N)$ \\
\hline$N$ & & $M . \operatorname{mountain}(N)$ & Cistus coast & $M . \operatorname{mountain}(N)$ & & M. mountain limestone $(N)$ \\
\hline$D$ & & Coast & Erica coast & Olive grove & & L. mountain gypsum $(N)$ \\
\hline$U$ & & & & Cork trees & & \\
\hline$S$ & & & & Pine trees & & \\
\hline $\boldsymbol{E}$ & & & & & & \\
\hline
\end{tabular}

The distribution of infiltration rates according to vegetation type suggests significant differences, with lower values found on bare soils, followed by grass, scrub and forest, and the higher values recorded in burned environments, such as burned scrub and burned forest (Fig. 6). The high variance in each type of vegetation, except for bare soil, can be partially explained by the large number of different land uses included in each category. This does not occur in the burned scrub group, whose wide dispersion of infiltration rates is linked to a single land use. The average and median values of each vegetation type suggest that the most significant differences observed in 
the transition between groups are from grass to scrub, and from forest to burned scrub, so that pairs of groups formed by bare soil-grass, forest-scrub and burned scrub-burned forest seem to show high similarities among each other. In any case, it is necessary to verify these observations through comparative statistical analyses (ANOVA and Bonferroni).

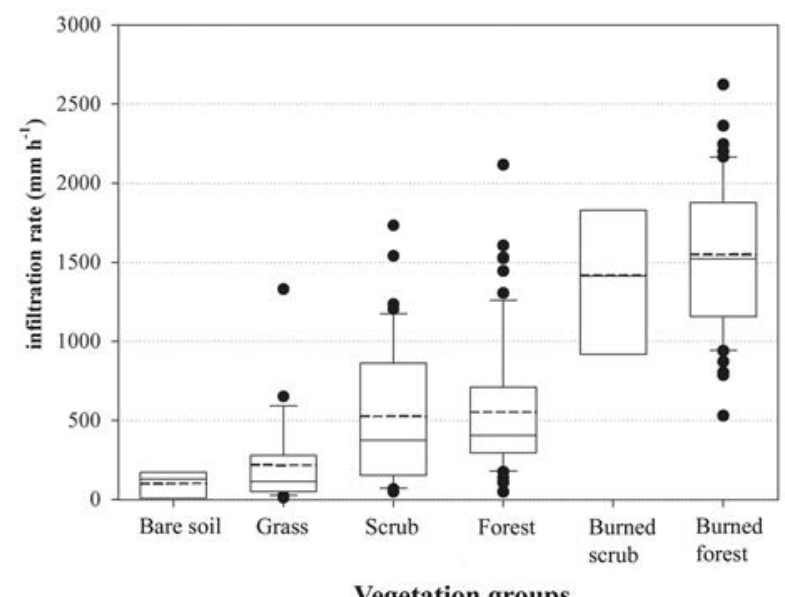

Figure 6. Infiltration rates for each vegetation type group (bare soil, grass, scrub, forest, burned scrub and burned forest).

Statistical results confirmed that the variance of infiltration rates can be explained by the type of vegetation cover, if only partially (Table 9). Differences were mostly found between burned environments and all other vegetation groups and between grass and forest. However, the coefficient between the grass and scrub groups is very close to the statistical significance (0.059), which is in agreement with the differences between the average and median values of infiltration rates of both groups (Fig. 6), but probably the null hypothesis is rejected by the extreme values included in the grass group. No significant differences were observed between the other vegetation groups. However, these results are somewhat surprising to say the least, since more differences could have been expected between bare soil and grass, scrub and forest groups. Probably the most decisive factor is the location of the study area and the fact that bedrock determines soil characteristics, although the effect of land use can also contribute to a large extent. These results confirm that the vegetation cover type is not a determining factor in explaining the variance in the infiltration process. However, these results suggest that some types of vegetation cover can affect the infiltration process more than others, since the statistical comparison returns significant differences, even if the analysis includes a variety of land uses and soil characteristics. 
Table 9. Comparison, through ANOVA and Bonferroni tests, of the infiltration rates returned for the type of vegetation cover. Significant coefficients are in bold.

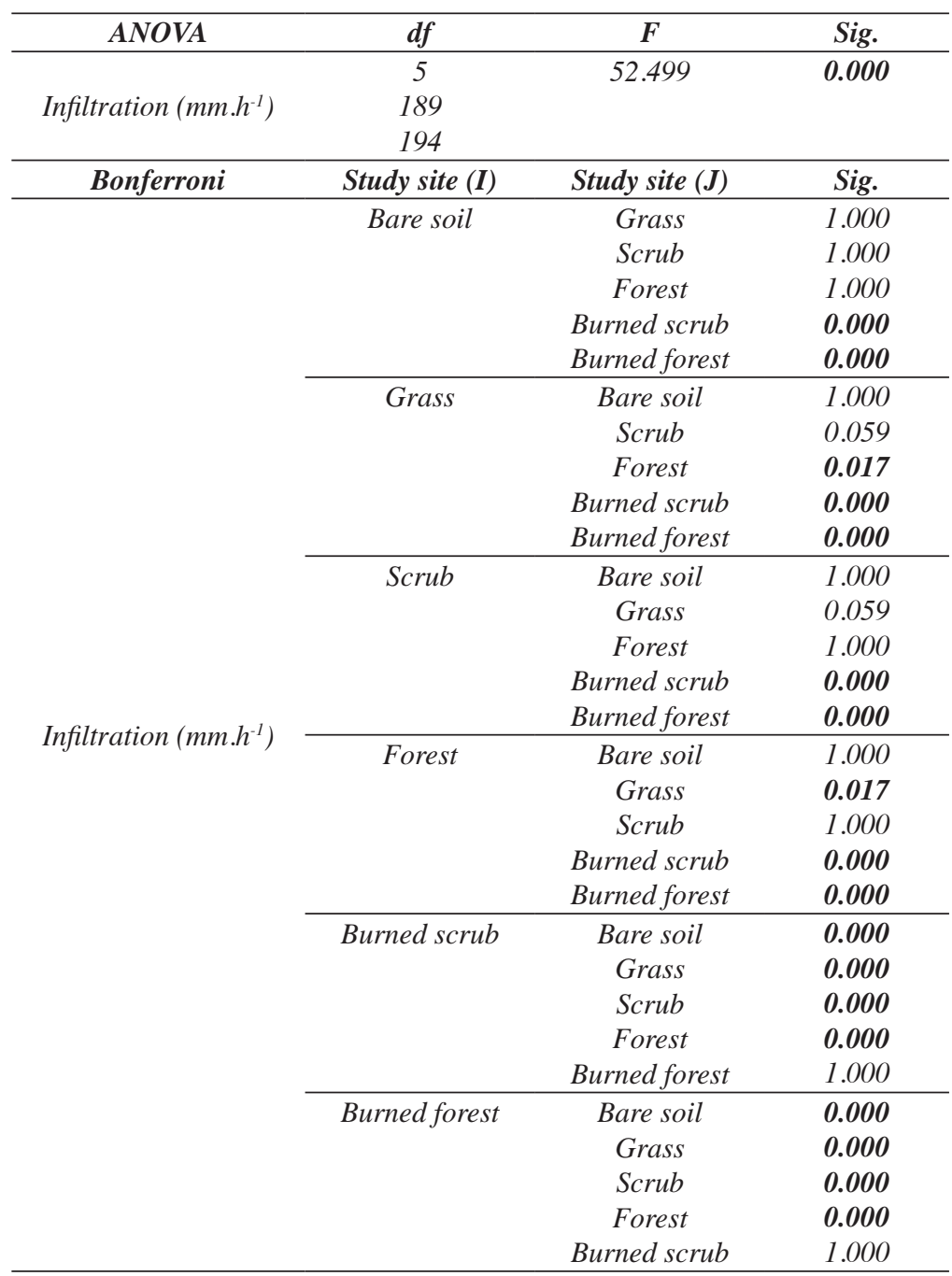

On the other hand, statistical descriptors of infiltration rates provide another option for analyzing differences between vegetation groups, by obtaining their quotients. Figure 7 shows the results of comparing correlative vegetation groups, following the same ascending order as given in Figure 6. This procedure has only been applied between successive groups to show results in a single graph. Descriptive values above 1 indicate an increase over a previous vegetation group and a quotient below 1 means a decrease. The first noteworthy item is that the differences do not affect all descriptors (i.e., average, median, maximum, minimum and standard deviation) equally, as there are large differences in one and very small ones in another. In this respect, it can be observed 
that the difference in maximum rate of infiltration between bare soil and burned forest is practically the same as between bare soil and grass. The same occurs with the standard deviation, which shows the largest variation between bare soil and grass, but varies very little among the following groups until reaching burned forest. However, average, median and minimum values show significant variances between grass and burned scrub, especially in the minimum rate of infiltration. This means that the vegetation cover has little influence on the initial infiltration capacity, but it does have a determining effect on the persistence and stability of the infiltration process. The second is the large difference in minimum infiltration rates between burned scrub and forest, which logically must be greater if compared with the scrub, grass and bare soil groups. The third observation is the great similarity between both scrub and forest, likewise observed between burned scrub and burned forest.

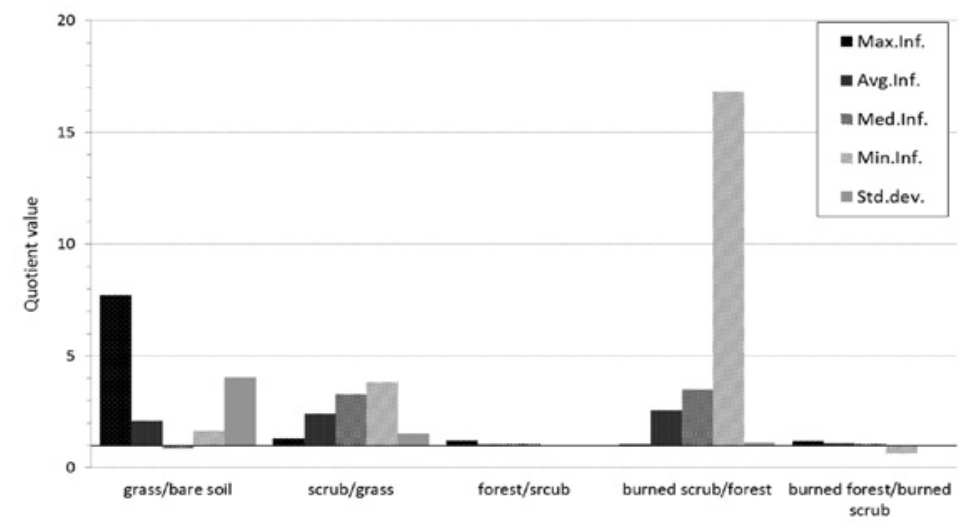

Figure 7. Quotient between the statistic descriptors of infiltration from correlative vegetation groups, following the order shown in Figure 6.

This method of comparison coincides quite well with the results of the statistical comparison, but also shows some differences that, without being statistically significant, should not be neglected.

\section{Discussion}

\subsection{Effect of the study site}

The first factor is linked to the characteristics of each study area, which includes geographical, topographical and geological aspects determining the type of soil and its physical properties, which are critical for the hydrological response (Rawls et al., 1993) and hydric properties (Seeger et al., 2006). Only infiltration rates showed clearly different ranges in the three study areas, but this was not observed with moisture values (Fig. 3 and Table 5). The effect of moisture has been evaluated in some studies in the opposite way, as a determining factor which can positively affect the infiltration capacity (Kirkby, 1978), since moisture is one variable that can influence the temporal evolution 
of surface hydraulic conductivity (Zhou et al., 2008). Although, it has been observed that the relationship between these two variables may depend on the degree of development of soil and vegetation cover (Regüés et al., 2012), or even that there may be no relationship (Hu et al., 2009). In this study, the variability of infiltration rates was separate from soil moisture (Table 4).

In any case, it must be noted that the Pyrenees (Jaca) area showed the lowest average infiltration values, at a ratio of 1:2 against the northeastern coast (Cap de Creus), and 1:6 for the Ebro valley (Zuera), and also returned the smallest range of dispersion (Fig. 3A). However, the moisture values indicated that the northeastern coast (Cap de Creus) is the driest area and showed less fluctuation, while the moisture values in the Ebro valley (Zuera) and Pyrenees (Jaca) areas were significantly higher and more similar (Fig. 3B). It seems obvious, even without looking at the statistics, that moisture values do not explain the differences in infiltration rates from the three study areas because of the absence of proportionality among them.

\subsection{Effect of land use}

Land use classification by ascending infiltration rates (Fig. 2) was used to analyse the statistical descriptors of infiltration rates and revealed that the classification is strongly influenced by the study area (Fig. 4), while moisture distribution shows no relation to land use (Fig. 5). Comparative statistics between infiltration rates and land use returned only a few differences but several similarities (Table 6), even when the analysis was done in the respective study sites, although in this case more differences among land uses were detected (Table 7).

These results are partially consistent with findings from previous studies, which have shown that different land uses are associated with different physical, chemical and biological properties of soils (Badía and Martí, 2003; Pardini et al., 2004a) determining their hydric properties and infiltration capacity (Boarmann and Klaassen, 2008; Zhou et al., 2008; Hu et al., 2009). Previous work has shown that both the infiltration capacity and saturated hydraulic conductivity are particularly sensitive to changes in land use (Alegre and Cassel, 1996; Schoenholtz et al., 2000; Zimmerman et al., 2006; Hu et al, 2009). It has also been observed that the dispersion of infiltration rates in a type of land use can be very high and is probably associated with temporal and spatial variations of hydric properties of the soils (Sisson and Wierenga, 1981; Mallants et al., 1996; Moret and Arrúe, 2007; Li et al., 2009). This variability may be even greater than that observed among different land uses (Zahou et al, 2008; Hu et al, 2009). This information agrees with the results from our study, where the variance of infiltration rates is probably due to differences in conditions in the study sites, rather than to those of land use.

Land use classification shows that the order of infiltration rates adheres quite closely to differences among the three study areas (Fig. 3A). It also shows that, with this grouping, land use classification for comparable vegetation cover types tends to be close. Lower infiltration values are generally linked to land use with less developed vegetation cover and soil (Tables 2 and 3). Intermediate infiltration values relate to scattered trees 
or scrub, followed by forest, and the highest infiltration values are frequently present in scenarios affected by fires. However, it is surprising to find coastal vineyards in the upper middle part of the classification. The higher infiltration rates found in these vineyards may be because it is a semi-abandoned crop and, as has been observed in previous studies, agricultural practices can result in a significant temporary variation of the infiltration capacity (Zhou et al., 2006). This explains the differences with the infiltration rates of land uses with scrubs, except for the land use burned scrub gypsum in the northeastern coast (Cap de Creus). The infiltration capacity in meadows is reduced by grazing (Godsey and Elsenbeer, 2002; Zimmerman and Elsenbeer, 2008), which agrees with the lower infiltration rates recorded in the south-facing pasture meadow in the Pyrenees (Jaca) or in the north-facing pasture meadow in the northeastern coast (Cap de Creus) compared with north-facing meadow in the Pyrenees (Jaca). It should also be noted that the exposure of the slopes is one of the determining factors explaining infiltration rate variation in land use in the Pyrenees (Jaca) where south-facing slopes have less developed soil and vegetation cover than the north ones (Navas et al., 2008; Reguiés et al., 2012), and this is why infiltration rates in south-facing forests and pasture are so low in relation to similar land uses on north-facing slopes. This effect has also been observed among the north and south burned forest of the Ebro valley.

\subsection{Effect of vegetation cover}

The third explanatory factor of infiltration rates is the type of vegetation cover. The infiltration rate classification according to the type of vegetation shows that both, the magnitude and dispersion of the values, are different for each group (Fig. 6). The comparative statistical analysis confirms that vegetation cover has some effect on infiltration rates (Table 9). It is important to note that the infiltration variability range in vegetation groups is higher than for land use (Fig. 4), which results from integrating different study areas and land uses into several vegetation groups, except those of bare soil and burned scrub (Table 8).

Previous studies provide useful information that can be assimilated into the results of this study. Low infiltration rates are recorded in bare soil due to the typical surface sealing in badlands (Regüés and Gallart, 2004; Nadal-Romero and Regüés, 2009), which agreed with the properties of soils developed on marls (Badía et al., 2015). Slope aspect has often been identified as a factor that determines soil degradation, vegetation cover and infiltration rates (Seeger et al., 2006; Regüés et al, 2012; Robertson and Sharp, 2015), especially in areas affected by farmland abandonment (Lana-Renault, 2009).

Significant differences were observed between grass and forest, but not between scrub with grass and forest (Table 9), although the difference between grass and scrub is very close to the statistical significance mentioned above (paragraph 3.3). This can also be seen from the statistical descriptors (Fig. 6). Since scrub and forest show similar infiltration rates, our analysis focuses on the differences between grass and forest (which can be comparable to differences between grass and scrub). Differences in infiltration capacity between grasses and forest are usually associated with the hydric properties of forest soils, which are more stable in depth than in other environments 
(Price et al., 2010). The saturated hydraulic conductivity $\mathrm{K}_{\text {sat }}$ at depth is also lower in meadow than forest soils (Alegre and Cassel, 1996; Martinez and Zinck, 2004; Price et al., 2010). It has been estimated that, in some cases, infiltration capacity in forest compared to meadow and pasture can be more than one order of magnitude higher (Zimmermann et al., 2006). Our study estimated a difference between forest and grass of about 2.5:1 for the average rate (Fig. 7). It was also observed that deforestation causes a reduction in infiltration capacity (Ghuman et al., 1991) and increases the frequency and duration of the occurrence of perched water tables (Cox et al., 1996; Rochefeller et al., 2004 Lana-Renault et al., 2007). In contrast, runoff in forest environments basically depends on sub-surface flows (Freeze, 1977; Beven, 1982; Serrano-Muela et al., 2008) so that groundwater levels fluctuate rapidly and do not reach the surface (Germer et al., 2010; Serrano-Muela et al., 2010). In this regard, it is clear that the expansion of scrub and forest have hydrological consequences (GarcíaRuiz and Lana-Renault, 2011).

There was a notable increase in infiltration rates between forest and burned scrub, especially for the minimum values, which was not observed between burned scrub and burned forest; this agreed with the slight differences observed between scrub and forest (Fig. 7). These differences could be related to the higher dispersion of the values in the forest group (which may be related to the fact that this group includes forests from the three study areas), whereas burned scrub only includes one land use in one study area (Table 8). In any case, these differences would agree with the results of previous studies, which found that the infiltration capacity of soils affected by fire increases after being covered by ash (Ebel et al., 2012; Leon et al., 2015b). Finally, despite the similarities shown by statistical comparison between the burned scrub and burned forest groups, it is worth mentioning some differences in comparative land uses of burned forest (Table 7 and Fig. 4). Thus, gypsum soils generally have a lower infiltration capacity than calcareous soils, as has been observed in previous studies (Cerdà, 1996; Badía and Martí, 2000), although the aforementioned effect of ash cover on gypsum soils is less evident than on calcareous soils (León et al., 2015b). The small effect of the ash layer on the infiltration rates of gypsum soils is evident from the comparison between gypsum forest and gypsum burned forest. However, this effect is less evident between scrub gypsum and burned scrub gypsum, which show important differences in infiltration rates.

\section{Conclusions}

The study of a wide variety of land uses, in 20 scenarios located in three different areas in Spain has enabled differentiating factors that best explain the variability of infiltration capacity. The most decisive ones are related to the characteristics of the study area, including soil type, land use and the type of vegetation cover. There does not seem to be a link with the preceding soil water status, although it might have an effect on a single land use. Therefore, the differences must relate to a combination of several factors, indicating the complexity inherent in carrying out comparative studies that include a wide range of scenarios. 
The comparative analysis of infiltration rates linked to a large number of land uses allows accurate evaluations of the cause-effect relationships. This provides more detailed information than that obtained by grouping land uses into types of vegetation cover, although the more general analysis based on types of vegetation cover can turn out to be even more interesting, because it provides general information that could be valuable for land management on larger scales. As an example, the infiltration capacity of forest soils, compared with grass and pastures, results in an increase similar to that observed in previous studies, although significantly lower in our case. This might be a consequence of integrating several study areas from different experimental sites. In fact, an important conclusion from the analysis is the confirmation that variance of infiltration rates associated with land uses can be less than the variance between different study areas.

The results from this study contribute additional insights into the hydric effects from changes in land use, providing information that can be used to assess the implications of changes in vegetation cover in the hydrological balance. The importance of this information is related to the current expansion of forest cover, causing a reduction in flow rates and availability of water for storage. The most valuable result provided by this comparative analysis is probably the integration of data from different areas representative of several environments in the Mediterranean basin. This fact can be considered as a useful reference, both from the scientific and socio-economic point of view.

\section{Aknowledgements}

Field infiltration tests were done with a grant from the CETSUS (CGL20076644-C04-01/HID) project funded by the "Plan Nacional I+D+I 2004-2007" from the Spanish Ministry of Science and Innovation. The current analysis and all the expenses associated with the publication of this study were funded by ESPAS project Ref.: CGL201565569-R (MINECO/FEDER). Estela Nadal-Romero is the recipient of a "Ramón y Cajal" postdoctoral contract (Spanish Ministry of Economy and Competitiveness).

\section{References}

Alegre, J.C., Cassel, D.K. 1996. Dynamics of soil physical properties under alternative systems to slash-and-burn. Agriculture, Ecosystems and Environment 58 (1), 39-48. http://doi. org/10.1016/0167-8809(95)00654-0.

Alonso-Sarría, F., Martínez-Hernández, C., Romero-Díaz, A., Cánovas-García, F., GomarizCastillo, F. 2016. Main environmental features leading to recent land abandonment in murcia region (southeast spain). Land Degradation \& Development 27(3), 654-670. http://doi. org/10.1002/ldr.2447.

Andréassian, V. 2004. Water and forest: from historical controversy to scientific debate. Journal of Hydrology 291 (1-2), 1-27. http://doi.org/10.1016/j.jhydrol.2003.12.015.

Arnáez, J., Lasanta, T., Errea, M.P., Ortigosa, L. 2011. Land abandonment, landscape evolution, and soil erosion in a Spanish Mediterranean mountain region: the case of Camero Viejo. Land Degradation \& Development 22, 537-550. http://doi.org/10.1002/ldr.1032.

Badía, D., Martí, C. 2000. Seeding and mulching treatments as conservation measures of two burned soils in Central Ebro Valley, NE Spain. Arid Soil Research and Rehabilitation 14, 219-232. http://doi.org/10.1080/089030600406635. 
Badía, D., Martí, C. 2003. Plant ash and heat intensity effects on chemical and physical properties of two contrasting soils. Arid Land Research and Management 17, 23-41. http://doi. org/10.1080/15324980301595.

Badía, D., Martí, C., Aguirre, J. Echeverría, M.T., Ibarra, P. 2008. Erodibility and hydrology of arid burned soils: soil type and revegetation effects. Arid Land Research and Management 22, 286-295. http://doi.org/10.1080/15324980802388231.

Badía, D., Martí, C., Aznar, J.M., León, J. 2013. Influence of slope and parent rock on soil genesis and classification in semiarid mountain environment. Geoderma 193-194, 13-21. http://doi. org/10.1016/j.geoderma.2012.10.020.

Badía, D., Orús, D., Doz, J.R., Casanova, J, Poch, R.M., García-González, M.T. 2015. Vertic features in a soil catena developed on Eocene marls in the Inner Depression of the Central Spanish Pyrenees. Catena 129, 86-94. http://doi.org/10.1016/j.catena.2015.03.006.

Beguería, S., López-Moreno, J.I., Lorente, A., Seeger, M., García-Ruiz, J.M. 2003. Assessing the effect of climate and land-use changes on streamflow in the Central Spanish Pyrenees. Ambio, 32 (4), 283-286. http://doi.org/10.1639/0044-7447(2003)032[0283:ATEOCO]2.0.CO;2.

Beven, K. 1982. On subsurface stormflow: an analysis of response times. Hydrological Sciences Journal, 27 (4), 505-521. http://doi.org/10.1080/02626668209491129.

Bodí, M.B., Doerr, S.H., Cerdà, A., Mataix-Solera, J. 2012. Hydrological effect of a layer of vegetation ash on underlying wettable and water repellent soil. Geoderma 191, 14-23. http:// doi.org/10.1016/j.geoderma.2012.01.006.

Bonell, M., Gilmour, D.A., Cassels, D.S. 1983. A preliminary survey of hydraulic properties of rainforest soils in tropical north-east Queensland and their implications of the runoff process. In: J. De Ploey (Ed.), Rainfall simulation, runoff and soil erosion. Catena Supplement 4, 57-78.

Bosch, J.M., Hewlett, J.D. 1982. A review of catchment experiments to determine the effect of vegetation changes on water yield and evapotranspiration. Journal of Hydrology 55 (1-4), 3-23. http://doi.org/10.1016/0022-1694(82)90117-2.

Bormann, H., Klaassen, K. 2008. Seasonal and land use dependence variability of soil hydraulic and soil hydrological properties of two northern German soils. Geoderma 145 (3-4), 295302. http://doi.org/10.1016/j.geoderma.2008.03.017.

Brown, A.E., Zhang, L., McMahon, T.A., Western, A.W., Vertessy, R.A. 2005. A review of paired catchment studies for determining changes in water yield resulting from alterations in vegetation. Journal of Hydrology 310 (1-4), 28-61. http://doi.org/10.1016/j. jhydrol.2004.12.010.

Camarero, J.J., García-Ruiz, J.M., Sangüesa-Barreda, G., Glaván, D., Alla, A.Q., Sanjuán, Y., Beguería, S., Gutiérrez, E. 2015. Recent and intense dynamics in a formerly static Pyrenees treeline. Artic, Antartic and Alpine Reseach 47(4), 773-783. http://doi.org/10.1657/ AAAR0015-001.

Cerdà, A. 1996. Seasonal variability of infiltration rates under contrasting slope conditions in southeast Spain. Geoderma 69 (3-4), 217-232. http://doi.org/10.1016/0016-7061(95)00062-3.

Cerdà, A. 1999. Parent Material and Vegetation Affect Soil Erosion in Eastern Spain. Soil Science Society of America Journal 63 (2), 362-368. http://doi.org/10.2136/sssaj1999.03615995006 300020014x.

Cerdà, A., Doerr, S.H. 2008. The effect of ash and needle cover on surface runoff and erosion in the immediate post-fire period. Catena 74 (3), 256-263. http://doi.org/10.1016/j. catena.2008.03.010.

Cerdà, A., Giménez Morera, A., Burguet, M., Arcenegui, V., González Peñaloza, F.A., García-Orenes, F., Pereira, P. 2012. The Impact of the Farming, Abandonment and Agricultural Intensification on Loss of Water and Soil. The Example of the Northern Slopes of the Serra Grossa, Eastern Spain. Cuadernos de Investigacion Geográfica 38 (1), 75-94. http://doi.org/10.18172/cig.1276. 
Cox, J.W., Fritsch, E., Fitzpatrick, R.W. 1996. Interpretation of soil features produced by ancient and modern processes in degraded landscapes. VII. Water Duration. Australian Journal of Soil Research, 34 (6), 803-824. http://doi.org/10.1071/SR9960803.

Creus, J. 1983. El clima del Alto Aragón Occidental. Instituto de Estudios Pirenaicos, Jaca (Huesca), 109 pp.

Duan, R., Fedler, C.B., Borrelli, J. 2011. Field evaluation of infiltration models in lawn soils. Irrigation Sciences 29 (5), 379-389. http://doi.org/10.1007/s00271-010-0248-y.

Dunjó, G., Pardini, G., Gispert, M. 2003. Land use change effects on abandoned terraced soils in a mediterranean catchment, NE Spain. Catena 52 23-37. http://doi.org/10.1016/S03418162(02)00148-0.

Ebel, B.A., Moody, J.A., Martin, D.A. 2012. Hydrologic conditions controlling runoff generation immediately after wildfire. Water Resources Research 48, W03529. http://doi. org/10.1029/2011WR11470.

Emran, M., Gispert, M., Pardini, G. 2012. Comparing measurements method of carbon dioxide fluxes in a soil sequence under land cover changes in North Eastern Spain. Geoderma 170, 245-260. http://doi.org/10.1016/j.geoderma.2011.11.013.

Freeze, R.A. 1972. Role of subsurface flow in generating surface runoff: 2. Upstream source areas. Water Resource Research 8 (5), 1272-1283. http://doi.org/10.1029/WR008i005p01272.

Gallart, F., Llorens, P. 2003. Catchment management under environmental change: impact of land cover change on water resources. Water International 28 (3), 334-340. http://doi. org/10.1080/02508060308691707.

García-Ruiz, J.M., Regüés, D., Alvera, B., Lana-Renault, N., Serrano-Muela, P., Nadal-Romero, E., Navas, A., Latron, J., Martí-Bono, C., Arnáez, J. 2008. Flood generation and sediment transport in experimental catchments affected by land use changes in the central Pyrenees. Journal of Hydrology 356 (1-2), 245-260. http://doi.org/10.1016/j.jhydrol.2008.04.013.

García-Ruiz, J.M., Lana-Renault, N. 2011. Hydrology and erosive consequences of farmland abandonment in Europe, with special reference to the Mediterranean region: Areview. Agriculture, Ecosystems and Environment 140, 317-338. http://doi.org/10.1016/j.agee.2011.01.003.

Gartzia Arregi, M. 2016. Evaluación de los cambios en los pastos del Pirineo Central y su relación con los componentes agropastorales. Unpublished $\mathrm{PhD}$ Thesis, Universidad de Zaragoza, $208 \mathrm{pp}$.

Germer, S., Neill, Ch, Krusche, A.V., Elsenbeer, H. 2010. Influence of land-use changes on nearsurface hydrological processes: Undisturbed forest to pasture. Journal of Hydrology 380 (34), 473-480. http://doi.org/10.1016/j.jhydrol.2009.11.022.

Ghorbani Dashtaki, S., Homaee, M., Mahdian, M.H., Kouchakzadeh, M. 2009. Site-dependence performance of infiltration models. Water Resources Management 23 (12), 2777-2790. http:// doi.org/10.1007/s11269-009-9408-3.

Ghuman, B.S., Lal, R., Shearer, W. 1991. Land clearing and use in the humid Nigerian tropics. I. Soil physical properties. Soil Science Society of America Journal 55 (1), 178-183. http://doi. org/10.2136/sssaj1991.03615995005500010031x.

Giertz, S., Diekkrueger, B. 2003. Analysis of the hydrological processes in a small headwater catchment in Benin (West Africa). Physics and Chemistry of the Earth 28 (33-36), 1333 1341. http://doi.org/10.1016/j.pce.2003.09.009.

Godsey, S., Elsenbeer, H. 2002. The soil hydrologic response to forest regrowth: a case study from southwestern Amazonia. Hydrological Processes 16 (7), 1519-1522. http://doi.org/10.1002/ hyp.605.

Godsey, S., Elsenbeer, H., Stallard, R. 2004. Overland flow generation in two lithologically distinct rainforest catchments. Journal of Hydrology 295, 276-290. http://doi.org/10.1016/j. jhydrol.2004.03.014. 
Regués et al.

Haghighi, F., Gorji, M., Shorafa, M., Sarmadiam, F., Mohammadi, M.H. 2010. Evaluation of some infiltration models and hydraulic parameters. Spanish Journal of Agricultural Research 8 (1), 210-217. http://doi.org/10.5424/sjar/2010081-1160.

Herreros, J., Snyder, R.L. 1997. Aridity and irrigation in Aragon, Spain. Journal of Arid Environment 35, 535-547. http://doi.org/10.1006/jare.1996.0222.

Hopmans, J.W., Schukking, H., Torfs, P.J.J.F. 1988. Two-dimensional steady state unsaturated water flow in heterogeneous soils with autocorrelated soil hydraulic properties. Water Resources Research 24 (12), 2005-2017. http://doi.org/10.1029/WR024i012p02005.

Hu, W., Shao, M., Wang, Q., Fan, J., Horton, R. 2009. Temporal changes of soil hydraulic properties under different land uses. Geoderma 149 (3-4), 355-366. http://doi.org/10.1016/j. geoderma.2008.12.016.

Kirkby, M.J. 1978. Hillslope Hydrology. Wiley-Intersciences, Norwich, 389 pp.

Lal, R. 1996. Deforestation and land-use effects on soil degradation and rehabilitation in western Nigeria. 1. Soil physical and hydrological properties. Land Degradation \& Development 7 (1), 19-45. http://doi.org/10.1002/(SICI) 1099-145X(199603)7:1<19::AID-LDR212>3.0.CO;2-M.

Lana-Renault, N. 2011. El efecto de los cambios de cubierta vegetal en la respuesta hidrológica y sedimentológica de áreas de montaña: la cuenca experimental de Arnás, Pirineo Central. Consejo de Protección de la Naturaleza de Aragón, Zaragoza, 189 pp.

Lana-Renault, N., Latron, J., Karssenberg, D., Serrano-Muela, P., Regüés, D., Bierkens M.F.P. 2011. Differences in stream flow in relation to changes in land cover: comparative study in two sub-Mediterranean mountain catchments. Journal of Hydrology 411, 366-378. http://doi. org/10.1016/j.jhydrol.2011.10.020.

Lana-Renault, N., Latron, J., Regüés, D. 2007. Streamflow response and water-table dynamics in a sub-Mediterranean research catchment (Central Pyrenees). Journal of Hydrology 347 (3-4), 497-507. http://doi.org/10.1016/j.jhydrol.2007.09.037.

Lasanta, T. 1988. The process of desertion of cultivated areas in the Central Spanish Pyrenees. Pirineos 132, 15-36.

Lasanta, T., Vicente-Serrano, S.M. 2007. Cambios en la cubierta del Pirineo Aragonés en los últimos 50 años. Pirineos 162, 125-154. http://doi.org/10.3989/pirineos.2007.v162.16.

León, J., Echeverría, M.T., Badía, D., Martí, C., Álvarez, C. 2013. Effectiveness of Wood chips cover at reducing erosion in two contrasted burnt soils. Zeitschrift für Geomorphologie, Sup. Issues 57, 27-37. http://doi.org/10.1127/0372-8854/2012/S-00086.

León, J., Badía, D., Echeverría, M.T. 2015a. Comparison of different methods to measure soil erosion in the central Ebro Valley. Cuadernos de Investigación Geográfica 41 (1), 165-180. http://doi.org/10.18172/cig.2703.

León, J., Echeverría, M.T., Martí, C., Badía, D. 2015b. Can ash control infiltration rate after burning? An example in burned calcareous and gypseous soils in the Ebro Basin (NE Spain). Catena 135, 377-382. http://doi.org/10.1016/j.catena.2014.05.024.

Li, Y.X., Tullberg, J.N., Freebairn, D.M., Li, H.W. 2009. Functional relationships between oil water infiltration and wheeling and rainfall energy. Soil and Tillage Research, 104 (1), 156163. http://doi.org/10.1016/j.still.2008.10.023.

López-Moreno, N., Beguería, S., García-Ruiz, J.M. 2006. Trends in the high flows in the central Spanish Pyrenees: response to climatic factors or to land-use change? Hydrological Sciences Journal 15 (6), 1039-1050.

Malmer, A. 1996. Hydrological effects and nutrient losses of forest plantation establishment on tropical rainforest land in Sabah, Malaysia. Journal of Hydrology 174, 129-148. http://doi. org/10.1016/0022-1694(95)02757-2.

Malmer, A., Grip, H. 1990. Soil disturbance and loss of infiltrability caused by mechanized and manual extraction of tropical rain-forest in Sabah, Malaysia. Forest Ecology and Management 38 (1-2), 1-12. http://doi.org/10.1016/0378-1127(90)90081-L. 
Mallants, D., Mohanty, B.P., Jacques, D., Feyen, J. 1996. Spatial variability of hydraulic properties in a multi-layered soil profile. Soil Science 161 (3), 167-181.http://doi.org/10.1097/00010694199603000-00003.

Martínez, L.J., Zinck, J.A. 2004. Temporal variation of soil compaction and deterioration of soil quality in pasture areas of Colombian Amazonia. Soil and Tillage Research 75 (1), 3-18. http://doi.org/10.1016/j.still.2002.12.001.

Mbagwu, J.S.C. 1995. Testing the goodness of fit of infiltration models for highly permeable soils under different tropical soil management systems. Soil and Tillage Research 34(3), 199-205. http://doi.org/10.1016/0167-1987(95)00463-3.

Mishra, S.K., Tyagi, J.V., Singh, V.P. 2003. Comparison of infiltration models. Hydrological Processes 17 (13), 2629-2652. http://doi.org/10.1002/hyp.1257.

Molinillo, M., Lasanta, T., García-Ruiz, J.M. 1997. Managing Mountainous Degraded Landscapes after Farmland Abandonment in the Central Spanish Pyrenees. Environmental Management 21 (4), 587-598. http://doi.org/10.1007/s002679900051.

Moraes, J.M., Schuler, A.E., Dunne, T., Figueiredo, R.O., Victoria, R.L. 2006. Water storage and runoff processes in plinthic soils under Forest and pasture in eastern Amazonia. Hydrological Processes 20 (12), 2509-2526. http://doi.org/10.1002/hyp.6213.

Moret, D., Arrúe, J.L. 2007. Dynamics of soil hydraulic properties during fallow as affected by tillage. Soil and Tillage Research 96 (1-2), 103-113. http://doi.org/10.1016/j.still.2007.04.003.

Nadal-Romero, E., Regüés, D. 2009. Detachment and infiltration variations as consequence of regolith development in a Pyrenean badland system. Earth Surface Processes and Landforms 34 (6), 824-838. http://doi.org/10.1002/esp.1772.

Navas, A., Machín, J., Beguería, S., López-Vicente, M., Gaspar, L. 2008. Soil properties and physiographic factors controlling the natural vegetation re-growth in a disturbed catchment of the Central Spanish Pyrenees. Agroforestry Systems 72, 173-185. http://doi.org/10.1007/ s10457-007-9085-2.

Navar, J., Synnott, T.J. 2000. Soil infiltration and land use in Linares, NL, Mexico. Terra Latinoamericana 18, 255-262.

Noguchi, S., Kasran, B., Yusop, Z., Tsuboyama, Y., Tani, M. 2003. Depth and physical properties of soil in a forest and rubber plantation in peninsular Malaysia. Journal of Tropical Forest Science 15, 513-530.

Pardini, G., Gispert, M., Dunjó G. 2004a. Distribution patterns of soil properties in a rural mediterranean area in Northeastern Spain. Mountain Research and Development 24, 44-51. http://doi.org/10.1659/0276-4741(2004)024[0044:DPOSPI]2.0.CO;2.

Pardini, G., Gispert, M., Dunjó, G. 2004b. Relative influence of wildfire on soil properties and erosion processes in different Mediterranean environments in NE Spain. Science of the Total Environment 328, 237-246. http://doi.org/10.1016/j.scitotenv.2004.01.026.

Pereira, P., Cerdà, A., Úbeda, X., Mataix-Solera, J., Arcenegui, V., Zavala, L.M. 2015. Modelling the impacts of wildfire on ash thickness in a short-term period. Land Degradation \& Development 26 (2), 180-192. http://doi.org/10.1002/ldr.2195.

Poyatos, R., Latron, J., Llorens, P. 2003. Land use and land cover change after farmland abandonment. The case of a Mediterranean Mountain area (Catalan Pre-Pyrenees). Mountain Research and Development 23 (4), 362-368. http://doi.org/10.1659/0276-4741(2003)023[0362:LU ALCC]2.0.CO;2.

Price, K., Jackson, C.R., Parker, A.J. 2010. Variation of surficial soil hydraulic properties across land uses in the southern Blue Ridge Mountains, North Carolina, USA. Journal of Hydrology 383 (3-4), 256-268. http://doi.org/10.1016/j.jhydrol.2009.12.041.

Rawls, W.J., Ahuja, L.R., Brakensiek, D., Shirmohammadi, A. 1993. Infiltration and soil water movement. In: D. Maidment (Ed.), Handbook of Hydrology. McGraw-Hill New York, pp. 5.1-5.51. 
Regüés, D., Gallart, F. 2004. Seasonal patterns of runoff and erosion responses to simulated rainfall in a badland area in mediterranean mountain conditions (Vallcebre, southeastern Pyrenees). Earth Surface Processes and Landfoms 29 (6), 755-767. http://doi.org/10.1002/ esp.1067.

Regüés, D., Serrano-Muela, P., Nadal-Romero, E., Lana-Renault, N. 2012. Análisis de la variabilidad temporal de la infiltración en un gradiente de degradación de usos del suelo en el Pirineo Central. Cuaternario y Geomorfología 26, 9-28.

Robertson, W.M., Sharp, J.M. 2015. Estimates of net infiltration in arid basins and potential impacts on recharge and solute flux due to land use and vegetation change. Journal of Hydrology 522 , 211-227. http://doi.org/10.1016/j.jhydrol.2014.11.081.

Rochefeller, S.L., McDaniel, P.A., Falen, A.L. 2004. Perched water table responses to forest clearing in northern Idaho. Soil Science Society of America Journal 68 (1), 168-174. http:// doi.org/10.2136/sssaj2004.0168.

Romero-Díaz, A., Marín-Sanleandro, P., Sánchez-Soriano, M., Belmonte- Serrato, F., Faulkner, H. 2007. The causes of piping in a set of abandoned agricultural terraces in Mediterranean Spain. Catena 69, 282-293. http://doi.org/10.1016/j.catena.2006.07.008551.4(460)(063).

Sahin, V., Hall, M.J. 1996. The effects of afforestation and deforestation on water yields. Journal of Hydrology 178 (1-4), 293-309. http://doi.org/10.1016/0022-1694(95)02825-0.

Sanjuán, Y., García-Ruiz, J.M., Beguería, S., López-Moreno, J.I., Arnáez, J. 2013. Cambios en el piso subalpino de las montañas mediterráneas. Quercus 327, 44-50.

San Román Sanz, A., Fernández , C., Mouillot, F., Ferrat, L., Istria, D., Pasquali, V. 2013. Longterm forest dynamics and land-use abandonment in the Mediterranean mountains, Corsica, France. Ecology and Society 18 (2), 38. http://doi.org/10.5751/ES-05556-180238.

Schoenholtz, S.H., Van Miegroet, H., Burger, J.A. 2000. A review of chemical and physical properties as indicators of forest soil quality: challenges and opportunities. Forest Ecology and Management 138 (1-3), 335-356. http://doi.org/10.1016/S0378-1127(00)00423-0.

Seeger, M., Errea-Abad, M.P., Lana-Renault, N. 2006. Spatial distribution of soils and their properties as indicators of degradation/regradation processes in a highly disturbed Mediterranean mountain Catchment. Journal of Mediterranean Ecology 6 (1), 53-59.

Serrano-Muela, P., Lana-Renault, N., Nadal-Romero, E., Regüés, D., Latron, J., Martí-Bono, C., García-Ruiz, J.M. 2008. Forests and their hydrological effect in Mediterranean mountains: The case of the Central Spanish Pyrenees. Mountain Research and Development 28 (3), 279285. http://doi.org/10.1659/mrd.0876.

Serrano-Muela, P., Regüés, D., Nadal-Romero, P. 2010. La variabilidad temporal de la respuesta hidrológica de una pequeña cuenca mediterránea forestada del Pirineo Central. Pirineos 165, 193-213. http://doi.org/10.3989/Pirineos.2010.165010.

Shakesby, R., Doerr, S. 2006. Wildfire as a hydrological and geomorphological agent. EarthSciences Reviews 74, 269-307. http://doi.org/10.1016/j.earscirev.2005.10.006.

Shukla, M. K., Lal, R., Unkefer, P. 2003. Experimental evaluation of infiltration models for different land use and soil management systems. Soil Science 168 (3), 178-191. http://doi. org/10.1097/01.ss.0000058890.60072.7c.

Sisson, J.B., Wierenga, P.J. 1981. Spatial variability of steady-state infiltration rates as a stochastic process. Soil Science Society of American Journal 45 (4), 699-704. http://doi.org/10.2136/ss saj1981.03615995004500040005x.

Stednick, J.D. 1996. Monitoring the effects of timber harvest on annual water yield. Journal of Hydrology 176 (1-4), 79-95. http://doi.org/10.1016/0022-1694(95)02780-7.

Strock, J.S., Cassel, D.K., Gumpertz, M.L. 2001. Spatial variability of water and bromide transport through variably saturated soil blocks. Soil Science Society of American Journal 65 (6), 1607-1617. http://doi.org/10.2136/sssaj2001.1607. 
Trimble, S.W., Weirich, F.H., Hoag, B.L. 1987. Reforestation and the reduction of water yield on the southern piedmont since circa 1940. Water Resources Research 23 (3), 425-437. http:// doi.org/10.1029/WR023i003p00425.

Vicente-Serrano, S.M., Lasanta, T., Romo, A. 2004. Analysis of the spatial and temporal evolution of vegetation cover in the Spanish Central Pyrenees: the role of human management. Environmental Management 34 (6), 802-818. http://doi.org/10.1007/s00267-003-0022-5.

Wang, Y., Fan, J., Cao, L., Liang, Y. (2016). Infiltration and runoff generation under various cropping patterns in the red soil region of China. Land Degradation and Development 27 (1), 83-91. http://doi.org/10.1002/ldr.2460.

Zavala, L.M., Jordán, A., Gil, J., Bellinfante, N., Pain, C. 2009. Intact ash and charred litter reduces susceptibility to rain splash erosion post-wildfire. Earth Surface Processes and Landforms 34, 1522-1532. http://doi.org/10.1002/esp.1837.

Zhao, C., Gao, J., Huang, Y., Wang, G., and Zhang, M. 2016. Effects of Vegetation Stems on Hydraulics of Overland Flow Under Varying Water Discharges. Land Degradation \& Development 27 (3), 748-757. http://doi.org/10.1002/ldr.2423.

Zhou, X., Lin, H.S., White, E.A. 2008. Surface soil hydraulic properties in four soil series under different land uses and their temporal changes. Catena 73 (2), 180-188. http://doi. org/10.1016/j.catena.2007.09.009.

Ziegler,A.D., Giambelluca, T.W., Tran,L.T., Vana, T.T., Nullet, M.A., Fox, J., Wien, T.D., Pinthong, J., Maxwell, J.F., Evett, S. 2004. Hydrological consequences of landscape fragmentation in mountainous northern Vietnam: evidence of accelerated overland flow generation. Journal of Hydrology 287 (1-4), 124-146. http://doi.org/10.1016/j.jhydrol.2003.09.027.

Zimmermann, B., Elsenbeer, H., De Moraes, J.M. 2006. The influence of land-use changes on soil hydraulic properties: Implications for runoff generation. Forest Ecology and Management 222 (1-3), 29-38. http://doi.org/10.1016/j.foreco.2005.10.070.

Zimmermann, B., Elsenbeer, H. 2008. Spatial and temporal variability of soil saturated hydraulic conductivity in gradients of disturbance. Journal of Hydrology 361 (1-2), 78-95. http://doi. org/10.1016/j.jhydrol.2008.07.027. 